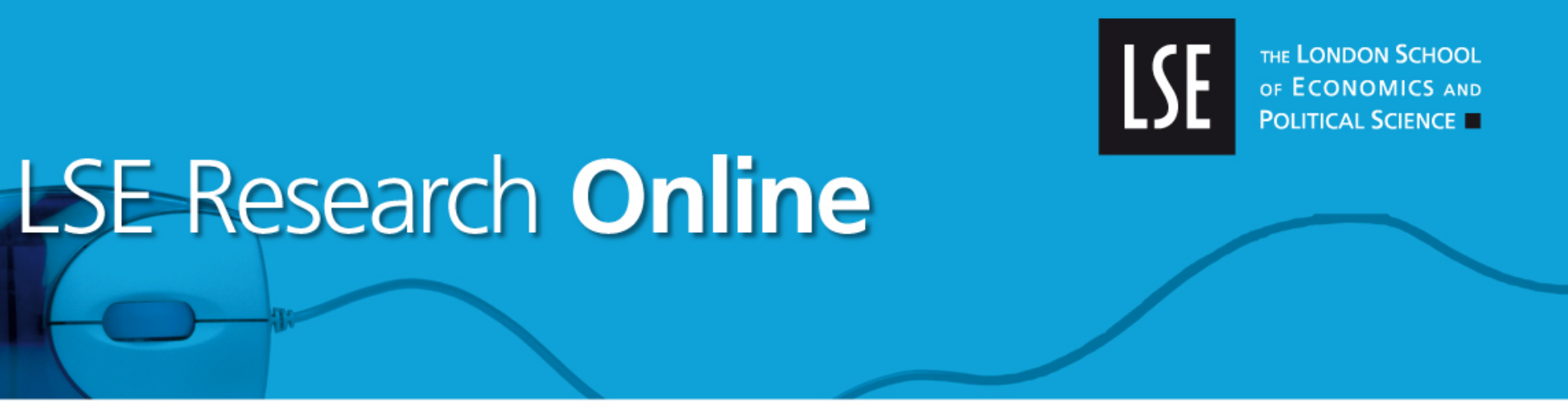

Matthew Cranford and Susana Mourato

\title{
Credit-based payments for ecosystem services: evidence from a choice experiment in Ecuador
}

\section{Item type \\ Article (Accepted version) (Refereed)}

\begin{abstract}
Original citation:
Cranford, Matthew and Mourato, Susana (2014). Credit-based payments for ecosystem services: evidence from a choice experiment in Ecuador. World Development. 64, pp. 503-520 ISSN 0305-750X
\end{abstract}

DOI: $\underline{10.1016 / j . w o r l d d e v .2014 .06 .019}$

Reuse of this item is permitted through licensing under the Creative Commons:

(C) 2014 The Authors CC-BY-NC-ND 4.0

This version available at: http://eprints.Ise.ac.uk/59067/

Available in LSE Research Online: Month Year

LSE has developed LSE Research Online so that users may access research output of the School. Copyright $(\subset$ and Moral Rights for the papers on this site are retained by the individual authors and/or other copyright owners. You may freely distribute the URL (http://eprints.Ise.ac.uk) of the LSE Research Online website. 
CREDIT-BASED PAYMENTS FOR ECOSYSTEM SERVICES: EVIDENCE FROM A CHOICE EXPERIMENT IN ECUADOR

Matthew Cranford (corresponding author)

Department of Geography and Environment

and the Grantham Research Institute on Climate Change and the Environment

London School of Economics and Political Science

Houghton Street

London WC2A 2AE

United Kingdom

m.c.cranford@1se.ac.uk

$+44(0) 2079557718$

Susana Mourato

Department of Geography and Environment

and the Grantham Research Institute on Climate Change and the Environment

London School of Economics and Political Science

Houghton Street

London WC2A 2AE

United Kingdom

s.mourato@1se.ac.uk 


\begin{abstract}
The original conceptualization of payments for ecosystem services (PES) promoted direct payments to motivate the provision of environmental public goods, but market imperfections and behavioral considerations can mean that PES that reduce market constraints are preferred. The main issue with the latter is how to include conditionality. We propose credit-based PES (CB-PES) as an incentive that links an environmental condition with the reduction of a key market constraint. Through a choice experiment in Ecuador, CB-PES was found to be a promising form of PES, with multiple desirable qualities of an incentive as cited in the behavioral economics and PES literatures.
\end{abstract}

Key Words: Payments for ecosystem services; credit; agroforestry; choice experiment; Ecuador; Latin America 


\section{ACKNOWLEDGEMENTS}

The Holly Hill Trust supported fieldwork for this paper; a special thank you to Martin Stanley of the trust. Rainforest Concern (RC) and Consorcio Toisan (CT) provided on-the-ground support in Ecuador. Thank you to Fiona Perez (RC) and Jose Cueva (CT) for providing significant logistical support and background information, and to Freddy Villalba, Gustavo Nogales, and Juan Guevara (all of CT) for their help with survey implementation. Additionally, thank you to Jefferson Mecham (ALLPA) and Maya Kocian (Earth Economics) for providing background information about the case study area; Charles Palmer (London School of Economics) for providing feedback on earlier versions of this paper; and to three anonymous reviewers for their comments that helped improve this paper. Finally, the lead author recognizes support from the UK Economic and Social Research Council. 


\section{INTRODUCTION}

There are various definitions of payments for ecosystem services (PES) (Muradian et al., 2010; Sommerville et al., 2009; Tacconi, 2012; Wunder, 2005), but all generally describe PES as positive and (at least somewhat) conditional incentives provided to induce a socially preferred environmental behavior. Over the past two decades, the use of PES to incentivize the provision of regulating and cultural ecosystem services (ES) has become increasingly popular around the world, including in developing regions. ${ }^{\mathrm{i}}$ It was initially argued that direct performance-based payments are the most costeffective form of incentive to induce the provision of ES and conservation of biodiversity (Ferraro \& Kiss, 2002; Ferraro \& Simpson, 2002). Where market constraints exist, however, indirect interventions that reduce them may be preferred by both the agent and the principal (Groom \& Palmer, 2010). In addition to economic constraints, current PES discourse references behavioral research exploring the efficacy of direct incentives, raising concern for the potential crowding-out of intrinsic motivation to provide ES (Farley \& Costanza, 2010; Muradian et al., 2010; Sommerville et al., 2009; Vatn, 2010). The key issue with alternative interventions, such as those that relieve market constraints, is that historically most have not been conditional and so do not ensure that conservation will occur (Wunder, 2005). Thus the key innovation that is required is to incorporate ES conditionality into the reduction of market constraints.

Discrete choice analysis (DCA) was originally developed to predict demand by consumers in traditional markets (Train, 2009). It is now also popular among environmental economists as a tool for understanding individuals' preferences for environmental attributes through stated preference (SP) studies (Hoyos, 2010). DCA has been used to evaluate preferences for forests (Brey, Riera, \& Mogas, 2007), wetlands (Carlsson, Frykblom, \& Liljenstolpe, 2003), beaches (Beharry-Borg \& Scarpa, 2010), landscape beauty (Dachary-Bernard \& Rambonilaza, 2012), fish (Agimass \& Mekonnen, 2011), and cultural heritage (Choi, Ritchie, Papandrea, \& Bennett, 2010), amongst many other environs and ES (see Atkinson, Bateman, \& Mourato, 2012 for a recent review of valuation of ES and biodiversity). Most applications are to understand preferences related to demand for ES, but DCA can also be used to understand preferences related to the supply of ES. It has begun to be used to ex-ante assess land or resource users' preferences for the attributes of incentive-based policies, such as agri-environmental 
schemes in Europe (Christensen et al., 2011; Espinosa-Goded, Barreiro-Hurlé, \& Ruto, 2010; Ruto \& Garrod, 2009), reforestation incentives in China (Grosjean \& Kontoleon, 2009), and marine PES (Barr \& Mourato, 2012).

The research presented here uses DCA to explore incorporating an environmental condition into what would previously be considered an indirect intervention for conservation that reduces market constraints. A choice experiment (CE) was carried out in Ecuador to estimate demand for credit that includes an environmental condition. The condition is such that if the borrower carries out the required environmentally friendly behavior, the cost of credit is reduced. That is a novel incentive called creditbased PES (CB-PES). Importantly, by estimating demand for such credit, observations can be made about the quality of CB-PES as an incentive in light of behavioral research that is cited in the PES literature. In doing so, this study adds to the literature in two ways. First, it adds to the few studies that empirically explore interventions to induce land use change through reducing market constraints in a PES context, and provides the first empirical research of incorporating strong conditionality into the provision of credit. Second, it also adds to the few studies that have used CE to explore policy design from the perspective of the agent supplying the desired policy outcome.

Following this introduction, section two reviews the relevant literature on PES and market constraints; motivation theory; and credit and environmental outcomes. Section three describes the case study and analysis carried out, section four explains the results of that study, and section five discusses the broader implications of those results. Section six concludes.

\section{TOWARD CREDIT-BASED PAYMENTS FOR ECOSYSTEM SERVICES}

The proposal of CB-PES is motivated by two considerations. The first is that market constraints can influence land-use decisions. Where conventional land-use is environmentally degrading, a transition to less damaging practices usually requires capital inputs. If capital constraints exist, it is arguably harder for a transition to the less degrading practices to occur, even in the presence of direct, demand-side incentives. The second consideration is motivation crowding. There is broad concern that direct 
payments can crowd out intrinsic motivations of the agent to provide positive environmental externalities, and thus reduce the effectiveness of those incentives. A credit-based intervention may be easier to align with the intrinsic motivations of the agent, and so be viewed as supportive, rather than coercive, which according to behavioral research would reduce the risk of crowding-out. The remainder of this section discusses both issue in more depth, and then reviews the literature on credit and environmental outcomes, leading to a conceptualization of CB-PES.

(a) Incentives that overcome market constraints

Payments for ecosystem services were originally conceptualized as direct payments for the output of ES or a land use that would generate that output (Wunder, 2005), and were believed to be an improvement over previous indirect approaches used in community conservation (Cranford \& Mourato, 2011). Community conservation comprises various indirect approaches (McNeely, Faith, \& Albers, 2005), but in the context of PES, indirect payments are often considered interventions that reduce the cost of inputs to activities that jointly produce private and public goods, or increase the price of the private good output (Ferraro \& Simpson, 2002; Groom \& Palmer, 2010). An example is providing the plants needed to establish a shade-grown coffee system, or ensuring there is a good price for the coffee produced.

Ferraro \& Kiss (2002) argue that using direct payments for the public good output is the first-best incentive-based policy primarily because it is the most cost-effective. Based on an economic model comparing direct payments and the indirect approach of reducing the cost of capital to a joint production activity, Ferraro \& Simpson (2002) conclude the same, and also show that the ES buyer and provider have opposing preferences, with the former preferring direct PES and the latter preferring indirect PES. In the context of developing countries, that result can be interpreted as a tension between environment and development outcomes (Groom \& Palmer, 2010) because direct payments will be more cost-effective for achieving environmental objectives, while indirect PES will be less costeffective for environmental outcomes, but more profitable for the presumably less-well-off ES provider. 
A key assumption of Ferraro \& Simpson (2002) was perfectly elastic markets for the inputs and outputs of the joint production activity. In a series of papers, Groom \& Palmer $(2009,2010,2012)$ remove that assumption and compare direct PES to the indirect approach of reducing capital constraints of a joint production activity. Where quantity constraints exist, there are situations where relaxing them can be more cost-effective than direct PES and preferred by both the ES buyer and provider (Groom \& Palmer, 2010). The chance of these results increases as 1) the return to scale of the productive activity increases towards constant (assuming diminishing returns to scale), and 2) there is input complementarity between the conservation action and capital used in the production process (Groom \& Palmer, 2012). At intermediate levels of returns to scale and complementarity, use of an indirect intervention may not be strictly cost-effective for environmental outcomes, but can still lead to an overall increase in welfare (Groom \& Palmer, 2012). Thus if the principal were concerned with improving welfare alongside environmental objectives, there is a greater chance they would prefer the indirect approach.

Supporting complementarity between household livelihoods and environmental outcomes, some PES programs incentivize agroforestry activities, including in Latin America (Corbera, Soberanis, \& Brown, 2009; Pagiola, 2008; Pagiola et al., 2007; Pagiola, Rios, \& Arcenas, 2010). That highlights a key overlap between the literature on PES and agricultural technology adoption. The most direct form of PES - to pay for quantified ES outputs-is a demand-side intervention that can be used to induce the adoption of particular agricultural practices. Many studies indicate that costly or lack of access to credit hinder the adoption and persistence of sustainable agriculture and agroforestry practices in the tropics (Blackman, Albers, Âvalos-Sartorio, \& Crooks, 2005; Mercer, 2004; Pagiola et al., 2007; S.K. Pattanayak, Mercer, Sills, \& Yang, 2003; Shively, 2001; Smith, Dubois, Current, Lutz, \& Clement, 1998) and credit constraints are a widely recognized constraint to the adoption of agricultural technologies generally (Feder \& Umali, 1993; Sunding \& Zilberman, 2001). Researching capital constraints broadly, Groom \& Palmer $(2009,2010,2012)$ focused on quantity constraints and illustrated that relieving them could be a preferred form of PES. Similarly in their review of the adoption of agricultural technologies, Sunding \& Zilberman (2001; pg. 248) explain in relation to price constraints for financial capital that "One approach to overcoming this obstacle is by credit subsidies 
for a new technology, which may be appropriate in situations when investments generate positive externalities." Relieving credit constraints, whether quantity or price, is thus a viable option for PES design from the perspective of agricultural technology adoption.

Previous studies have compared a direct, conditional incentive with relieving market. The debate about which is better, hinged on how strong the conditionality of the incentive is, and the degree to which local markets were elastic in relation to the inputs and outputs of the eco-production process. That included an inherent assumption that an incentive could not both be conditional and relieve market constraints. The current paper is unique, and advances that debate, because it focuses on an incentive designed to relieve market constraints, but that includes a strict environmental conditionality.

(b) Incentives that account for motivation crowding

Motivation crowding theory posits that the increase in supply of pro-social behavior induced by providing an external incentive (i.e., the price effect) can, under different conditions, be dampened or heightened due to a crowding-out or crowding-in of intrinsic motivation of the agent to carry out the task (i.e., a behavioral effect)(Frey \& Jegen, 2001). Many researchers and practitioners have highlighted concern that crowding-out may occur with PES (Farley \& Costanza, 2010; Muradian et al., 2010; Sommerville et al., 2009; Vatn, 2010), thus decreasing the effectiveness of the incentive to induce greater supply of ES, but this remains an unresolved issue in PES design (Ferraro, Lawlor, Mullan, \& Pattanayak, 2012; Subhrendu K. Pattanayak, Wunder, \& Ferraro, 2010).

Three broad mechanisms have been identified through which crowding-out occurs (based on Bowles, 2008; Frey \& Jegen, 2001; with examples of experimental and theoretical research cited):

- The introduction of incentives suggests self-interest as the appropriate behavior in place of pro-social behavior (Cardenas, Stranlund, \& Willis, 2000), which can lead to changes in endogenous preferences that persist in time (Gneezy \& Rustichini, 2000).

- Incentives compromise the individual's self-determination, so intrinsic motivation is no longer justified (Bénabou \& Tirole, 2006). 
- The act of providing incentives signals something about the activity to be carried out that demotivates the agent (Bénabou \& Tirole, 2003).

Additionally, there is specific concern about providing cash rewards as PES. The introduction of money can induce a psychological orientation of self-sufficiency (Vohs, Mead, \& Goode, 2006) increasing the concern that cash PES may crowd-out intrinsic motivations via the mechanism of increasing self-interest, which could spill over into other parts of life.

An external incentive can also have a crowding-in effect. Broadly, if the reward is perceived as supportive rather than coercive, it can crowd-in intrinsic motivation to carry out a task (Frey \& Jegen, 2001; Vollan, 2008). That aligns with calls to frame PES as a reciprocal or co-investment arrangement (Farley \& Costanza, 2010; van Noordwijk \& Leimona, 2010). Where there is a diversity of preferences related to markets and self- or other-regarding behavior, policy-makers must consider the specific implementation context in order to ensure incentive-based policies are designed and framed optimally. Narloch, Pascual, \& Drucker, (2012) empirically demonstrate that differing preexisting preferences of the ES provider related to markets and self-regarding behavior can influence the optimal design of PES in Latin America.

In addition to linking an environmental condition to relieving market constraints, the second motivation for studying CB-PES is to see what observations can be made in light of results from research on motivation crowding. A credit-based incentive intuitively fits the concept of a supportive, rather than coercive incentive, which would make it less likely to crowd-out intrinsic motivation. Through observing expected demand for credit with an environmental condition, conclusions can be made on how CB-PES fits this concept of a supportive incentive, in particular as it is discussed in the PES literature.

(c) Credit and environmental outcomes

There is a small literature on the interactions of credit and natural resource management (NRM) that is rooted in microfinance literature and relevant here. It is understood that microfinance institutions 
(MFIs) can impact NRM by effecting changes in physical, human, and social capital that interact with natural resources (Anderson, Locker, \& Nugent, 2002), but there is increasing attention paid to strengthening the link between credit provision and specific environmental outcomes. Allet (2011) focused on MFIs, and identified five strategies that financial institutions can employ to manage their environmental impact: 1) adopting environmental policies, 2) reducing the institution's internal ecological footprint, 3) managing portfolio environmental risks, 4) providing green microcredit, and 5) providing environmental non-financial services. The latter three strategies include different approaches to linking the provision of credit to environmental outcomes. Environmental organizations are also starting to implement these strategies, as well as introducing some of their own innovations to link credit provision with environmental outcomes. The resulting five approaches are summarized in Table 1.

\section{TABLE 1 ABOUT HERE}

The approaches established by financial institutions make credit provision weakly conditional on environmental outcomes. The first is selective lending, either through negative screening to exclude certain activities or borrowers with high environmental risk (Allet, 2011), or by positive selection of inherently environmentally friendly enterprises, such as ecotourism projects (e.g. Conservation International 2013; EcoEnterprises Fund 2012; Proyecto CAMBio 2013). The second approach is concessional lending, which expands on selective lending, such that financed activities receive favorable lending terms (e.g. Annex 2 in Greiber 2009). Selective lending and concessional lending are the two types of lending typically considered green (micro-) credit (Allet, 2011) and would be considered an indirect intervention to improve conservation via the mechanism of reducing market constraints (Ferraro \& Kiss, 2002; Groom \& Palmer, 2009). The third approach is where access to credit is not coupled to the inherent environmental friendliness of the activity to be financed, but conditional on meeting environmental covenants, which may or may not be directly related to the financed activity (Anderson et al., 2002; Assunção et al., 2013; Senaratna Sellamuttu, de Silva, Nguyen Khoa, \& Samarakoon, 2008; Yuhe \& Yi, 2000). 
There are two approaches developed by conservation organizations to make credit provision more strongly conditional on an ecological objective. The first is to link access to credit to conservation outcomes. Mandel et al. (2009) proposed an environmental mortgage, where a community development fund would be capitalized to an amount that is correlated to the value of natural capital that the community is charged to protect. The natural capital acts as collateral against the value of the fund, and if it degrades, the size of the community fund would be decreased. Activities financed by the fund would not specifically face an environmental conditionality, but would need to be environmentally neutral or positive to ensure that they do not degrade the natural capital collateral.

The second approach is to make the cost of credit dependent on an environmental outcome. An environmental condition can be included in the loan contract, such that the interest rate is lowered if the condition is met but is not lowered if the condition is not met. In other words, if the condition is met, a portion of the annual repayment is forgiven, either directly by the credit provider or by a third party paying a portion of the repayment. This is called credit-based payment for ecosystem services (CBPES) (Figure 1). Concessional lending ex-ante subsidizes credit and only lends to activities that are inherently environmentally friendly. In contrast, CB-PES is rewarded ex-post, if, and only if, the environmental condition is met. Additionally, the activity to be financed can be decoupled from the environmental objective, although as with environmental mortgages, it should be environmentally neutral or positive.

An intervention like CB-PES could be useful for both market and behavioral reasons. Where other interventions either aim to reduce market constraints or directly reward provision of ES, CB-PES links these two objectives. It is the only known intervention to include a clear conditional link between ES provision and the reduction of market constraints where success of meeting the condition is determined ex-post. Additionally, by reducing market constraints and being voluntary in nature such that the potential ES provider must choose to take out a loan, CB-PES intuitively fits the framing of a supportive incentive. 
The examples that can inform CB-PES fall on either end of a spectrum of conditionality (Figure 1). At zero conditionality, some lenders include requirements for environmental actions in their contract (e.g. plant a tree) (Allet, 2011; Anderson et al., 2002) or require that borrowers adhere to environmental regulation (Assunção et al., 2013) in order to access credit, but if the condition is not met, there is no change in the required repayment, and no other immediate reward or punishment. That is the covenants approach to linking credit and environment described above and in Table 1.

\section{FIGURE 1 ABOUT HERE}

At $100 \%$ conditionality, if the environmental condition is met, the loan is converted to PES and does not have to be repaid, which has been carried out in Asia and Africa (van Eijk \& Kumar, 2009). If the condition is not met, however, the loan must be repaid as normal.

Between these two ends of the spectrum lay possible mechanisms where credit is borrowed and if an environmental condition is met, the interest rate and thus the amount that must be repaid is lowered. To the best of our knowledge, only convertible (i.e. 100\% conditional) loans have been implemented, and these projects have reported success (van Eijk \& Kumar, 2009; Wetlands International, 2009).

\section{METHODS}

As discussed so far, for both economic and behavioral reasons, CB-PES could be a desirable incentive. To further explore this proposition, we carried out a $\mathrm{CE}$ to ex-ante assess the preferences for loan terms by small-scale agriculturalists living in an area where market constraints exist. Through implementing a CE among local households, we aimed to 1) understand farmers' preferences for loan attributes, including an environmental conditionality, 2) comment on CB-PES as an incentive, and 3) understand the broader dynamics of providing CB-PES.

(a) Case study of the Intag Zone of Ecuador 
The Intag Zone of Northern Ecuador (Figure 2) ranges over approximately 1500-4000 meters above sea level and includes the range of ecosystems seen across the Andes, from sub-tropical forest to páramo, including 44,000 hectares (Ha) of cloud forest (HidroIntag, 2009). The loss of cloud forests is detrimental to society as they are a source of many ES, and are particularly valuable for their high level of biodiversity and regulation of water quality and supply (Bubb, May, Miles, \& Sayer, 2004). Agricultural expansion is the greatest threat to cloud forests across Latin America (Bubb et al., 2004) and in the Ecuadorian Andes (Wunder, 1996). Along with timber collection, agricultural expansion has led to large-scale deforestation in Intag. With much of the forest already removed, the average annual deforestation rate from 2001 to 2006 was 1.92\% in Cotacachi Canton (Intag covers $75 \%$ of this canton) and $2.47 \%$ across the entire Imbabura Province in which Intag sits (Peck, 2009). Both rates are greater than the average across Ecuador during the same time period (FAO, 2010).

\section{FIGURE 2 ABOUT HERE}

The vast deforestation in Intag has led to a lower level of biodiversity habitat and multiple ES, which are valuable on local to global scales. Efforts to better conserve biodiversity and provide higher levels of ES in Intag have led to a recent focus on increasing agroforestry practices on private land. In Intag, an uptake of such practices helps to decrease pressures on forests, in part through broader acceptance of protected areas (Mecham, 2009). Additionally, ecologists and agricultural specialists working in Intag believe that agroforestry in the region directly provides key ES, in particular, increased biodiversity habitat, increased carbon sequestration and storage, reduced soil erosion and consequent siltation of waterways, and increased water regulation. Not only are those services immediately valuable, but they also support climate change adaptation in the region. Climate change is predicted to increase annual rainfall in the zone, ${ }^{\mathrm{ii}}$ and practices of forest conversion and monocropping have left a highland landscape with much less tree cover than is natural. Without improved land-use practices, increases in rainfall will increase runoff, reducing the productivity of farmland and increasing siltation in waterways, with potentially severe implications for food security. 
In addition to these environmental benefits, over the long run, properly designed agroforestry systems are more profitable than most conventional agricultural systems in the region. Table 2 presents the net present value (NPV) of three production systems that are not conventional in Intag, but produce greater levels of the environmental benefits noted above. They are shade-grown coffee, mixed agroforestry, and sustainable forestry patches included in the farm mosaic. ${ }^{\text {iii }}$ The NPV calculation includes all costs associated with establishing these new systems. For comparison, the NPV of ongoing cash flows associated with two conventional systems are also presented. The most prevalent conventional system is rotating maize and bean production, which provides two crops that can be consumed or sold by households. Sugar cane production is the only conventional system in the area that can compete in terms of income with the agroforestry systems. It is less prevalent throughout the region though, due to its high costs and the fact that it produces a cash crop and is not as useful for subsistence production. Two notable features of the comparison are that the agroforestry systems are more profitable than the most prevalent conventional systems, but will not be profitable for a few years after implementation. Even though shade-grown coffee and mixed agroforestry break even in year 2 and 3 respectively, neither reaches full productive capacity until year 4. Financing is needed to help bridge this temporal gap in profitability.

\section{TABLE 2 ABOUT HERE}

Households in Intag have increasingly practiced agroforestry since 1998 with the establishment of the Asociación Agroartesanal de Caficultores Rio Intag (AACRI), a local coffee cooperative. A UK-based organization, Rainforest Concern, also implemented a conservation project in the region to create the Chocó-Andean (ecological) Corridor including a 5,000-hectare area known as Paso Alto. A management plan for Paso Alto was developed by Rainforest Concern, AACRI, and ALLPA (a partner organization to AACRI), and agreed with the Ecuadorian Ministry of the Environment. Promoting sustainable agricultural practices is a significant part of that plan. Under the project, over 40 farms were provided finance to convert a one-hectare parcel of their land to agroforestry (mainly shadegrown coffee), with the aim that they would see the benefits and independently convert further land to agroforestry (Mecham, 2009). 
To date, however, the support for agroforestry practices has been grant-based. Further, agroforestry is still only practiced by a minority of households, and only on a small fraction of the land of those households. A major reason is that broad market constraints are present in the zone: Intag is remote and the terrain is tough, making it difficult to get supplies in and goods out. Post-production constraints are being reduced through cooperatives in the region that either purchase crops directly (as with AACRI and coffee) or are developing projects to support getting crops to market, such as an Intag store in the nearest major market town. Pre-production constraints, however, remain more difficult to remove. Specifically, although households in the region are familiar with credit, it is not readily available in the region, and local agricultural specialists believe that to be constraining the uptake of agroforestry systems (Arisman 2012; Cranford et al. 2010; Jose Cueva, personal communication). As predicted by Groom and Palmer (2010), with these market constraints in place, donors (the ES buyers) are interested in the potential for linking credit provision and conservation activities.

(b) Survey and choice experiment

A survey of households in Intag was carried out from August to mid-October, 2010. The sample was collected by local extension workers, which due to difficult terrain could only be done through opportunistic sampling, but with some guidance. Extension workers focused on communities situated on the south-eastern side of the Intag River, lying between the river and the Chocó-Andean corridor project noted above. Since some of the communities in this part of Intag have been engaged in shadegrown coffee or the specific pilot program to promote agroforestry as part of the Paso Alto management plan, the extension workers' aim was to collect a sample of households with a range of agroforestry experience. The extension workers also strived to collect surveys across a range of altitudes to ensure the sample included a diversity of ecosystem contexts and farm compositions that represented the zone and the Andes more broadly.

The main body of the survey collected information about each household's social characteristics, land ownership and use, crop production, livestock rearing, forest-related activities, and non-farm income. The latter portion of the survey collected information on their experience with and views towards 
agroforestry, which was followed by a CE. The CE was designed to determine a household's preference for the attributes of a loan, with particular focus on an environmental condition. The hypothetical situation presented was as realistic as possible and involved a conversation between the survey implementer and respondent that covered these key points:

- An organization could provide credit to some families in your community

- Credit could be borrowed for any purpose

- The organization would like to see an increase in agroforestry

- Some of the loans may have a lower interest rate and a condition that you must convert one hectare of your land to agroforestry

- That lower interest rate, however, is only available if you are able to meet the condition

- If you do not meet the condition, you will have to pay back the loan at normal interest rates (which are $12-18 \%$ in surrounding areas).

The attributes of the alternatives were basic loan characteristics, and the attributes and levels were determined through meetings with extension workers and local agricultural experts. The four attributes presented in the choice experiment (Table 3) were loan size (in US \$), maturity (years), conditionality (a binary variable), and annual interest rate (\%). To reduce cognitive burden, the average annual payment associated with the loan was listed as a value in US \$ alongside the interest rate as a percentage..$^{\text {iv }}$

\section{TABLE 3 ABOUT HERE}

The levels of the loan size and maturity were determined by ensuring that the middle level of each matched the amount of investment needed to meet the environmental condition and the timeframe over which a positive return on shade-grown coffee (the most prevalent form of agroforestry) would be realized. That information was based on the business models of agroforestry developed by local agricultural experts (Table 2). One level lower and higher than these middle levels were also included to ensure that the hypothetical loans could be decoupled from the environmental condition and used for other activities. The lower loans were too small and too short to provide the total support for 
conversion to any form of agroforestry, while the larger levels were too large and too long to be appropriate for the single, specific use of converting one hectare to agroforestry. ${ }^{\mathrm{v}}$

A full factorial design of the attributes produced 72 possible loans, which were reduced to 16 using an orthogonal design. From this fractional factorial design, a shifting procedure ${ }^{\mathrm{vi}}$ was used to create 16 pairs of 32 alternatives. Although this CE design approach is sometimes not viewed as the most efficient, it was deemed appropriate here due to the relatively small sample size and lack of a-priori information about the parameter values of the econometric model (Ferrini \& Scarpa, 2007).

Due to the condition attribute being binary, the shifting technique naturally produced 16 choice sets where there was always one conditional and one unconditional loan. The order of the two loan alternatives on each card was randomized (i.e., A, B vs. B, A), meaning that the CE was unlabeled. In addition to the conditional and unconditional loan options, each choice set included an option to not take any loan (an opt out/status quo option). An example of a choice card used during the survey is presented in Figure 3.

\section{FIGURE 3 ABOUT HERE}

The sample included 345 households in 50 of the approximately 76 rural communities in Intag ${ }^{\text {vii }}$ (Kocian et al., 2011). Due to the nature of the non-linear models used to analyze choice experiments, precisely determining the optimal sample size depends on having a-priori information about the values of the model parameters (Hoyos, 2010), which did not exist in this case. Nonetheless, rules of thumb are available to provide some confidence that a sample is large enough to produce stable estimates of the parameters. Orme (1998) as cited in Rose \& Bliemer (2008) reports the rule of thumb presented in Equation 1.

Equation 1: Estimating the minimum sample size for choice experiments.

$$
N=500 *\left(\frac{L}{J * T}\right)
$$

where $L$ is the largest number of levels for any attribute, $J$ is the number of alternatives per choice set, and $T$ is the number of choice sets for each respondent. In this study, for the initial $30 \%$ of respondents, 
only one randomly assigned choice set was answered in order to ensure the choice experiment was functioning properly, which it was. For the remaining $70 \%$ of the respondents, four choice sets were randomly assigned without replacement, and no other changes to experimental design were made. In relation to minimum sample size, the average number of choice sets per respondent was used for $T$ (i.e., 2.95 ), and the rule of thumb indicates a minimum sample size of 226 , which is $66 \%$ of the sample collected. Additionally, there is no standardized information available on the number of households in Intag, however it is broadly cited that there were approximately 17,000 inhabitants in the region around the time of this study (HidroIntag, 2009; Kocian et al., 2011). Based on the number of people reported dwelling in each household surveyed here, approximately $7.6 \%$ of the population of Intag was accounted for in this survey.

(c) Econometric framework and model specification

A mixed logit (MXL) model, also known as a mixed multinomial logit or random parameters logit, was used to analyze the CE. The MXL is able to approximate any logit model for discrete choices under utility maximizing behavior (McFadden \& Train, 2000). During the CE, each respondent was presented with multiple choices sets, so the random utility function with random parameters takes the form in Equation 2 (following Train 1998).

Equation 2: Random utility function with random parameters.

$$
U_{j n t}=\beta_{n} x_{j n t}+\varepsilon_{j n t}=b^{\prime} x_{j n t}+\eta_{n} x_{j n t}+\varepsilon_{j n t}
$$

where $U$ is the utility of alternative $j(\mathrm{i}=A, B, C)$ in choice set $t(t=1, \ldots, 4)$ to household $n(n=1, \ldots$, $N) . x_{j t n}$ is a vector of explanatory variables that are observed and include attributes of the alternatives, socio-economic characteristics, and potentially descriptors of the decision context. $\beta_{n}$ and $\varepsilon_{j t n}$ are stochastic influences not observed by the analyst and $\varepsilon_{j t n}$ is assumed to be independent and identically distributed (IID) extreme value type 1. Under a multinomial logit (MNL) model, $\beta$ is fixed across the population, but in a random parameters specification, the vector $\beta_{n}$ is expressed as the population means $b$ and individual deviations $\eta_{n}$ from those means to account for unobserved heterogeneity. The vector $\eta_{n}$ is correlated over alternatives and choices situations and can take various distributional forms 
across the population. The form can be different for each $x$ leading to a mixed distribution when estimating the econometric model.

The model is operationalized using a logit formula, the outcome of which is integrated over the mixture distribution of $\eta$ to determine the probability of the respondent $n$ choosing alternative $j$. The integral does not take a closed form and is estimated using simulation techniques. Estimation was carried out in Stata 11 using the mixlogit command (Hole, 2007). The final results from MXL are the estimation for each parameter of 1) the population mean, and 2) the standard deviation of the population around that mean, dependent on the distributional form the analyst applies to that parameter.

The MXL model was chosen here in order to remove the three restrictive assumptions of the more prevalent MNL models. ${ }^{\text {viii }}$ Specifically the MXL 1) does not assume independence from irrelevant alternatives (IIA) and so permits unrestricted substitution patterns, 2) can easily be adjusted to account for correlation in unobserved factors over choice situations, and 3) incorporates random parameter estimates to account for preference heterogeneity among respondents (Train, 2009).

The first point is important because early exploration of the data for this paper compared a nested logit to a MNL. It was found that there are unobserved factors that are constant over the unconditional and conditional loan alternatives that need to be accounted for. The MXL relaxes the IIA assumption and an analogue to a nesting structure can be incorporated into MXL by addition of a dummy variable for the hypothesized nest (Train, 2009), in this case a dummy variable for loan was included. Related to the second point, to account for repeated choices by each respondent, 1) the mixed logit model is specified so that the random parameters vary over individuals, but held constant over the choice sets each individual was presented with, and 2) the unconditional probability used for maximum simulated likelihood estimation is based on the probability of the sequence of choices made by an individual, not the probability of each choice treated separately (Train, 2009).

Finally, the third point is testable using a MXL. In this study the standard deviation of two attributes and the loan dummy variable entered the model with statistical significance, indicating they could be modeled as random to account for unobservable preference heterogeneity among households. Some 
preference heterogeneity is observable and introduced in the model through interactions between household characteristics and loan attributes.

The final variables used in the regression are presented in Table 4. In order, they include a dummy variable for the hypothesized nest of loan discussed above, the four loan attributes, and four respondent characteristics included as interactions with different loan attributes. The loan dummy variable was included to account for latent demand for credit, irrespective of whether or not it was conditional credit. The loan attributes are all included, to model respondent preferences for different credit terms. Finally, respondent characteristics were only introduced into the model specification process if there was a possible economic reason for them to interact with specific loan attributes. These interaction terms were introduced using a blocking approach in a nested logit specification, and those found to be statistically significant were maintained in the MXL models only if they passed a log-likelihood test compared to a model excluding them in the nested logit specification. Further detail of the estimated parameters associated with these interaction terms and economic reasoning for their inclusion is provided in Section 4(b).

\section{TABLE 4 ABOUT HERE}

One characteristic that was included through an interaction term, crop value, is a constructed variable, calculated using Equation 3.

Equation 3: Constructed variable of crop value.

$$
V_{n}=\sum_{c=1}^{C}\left(P_{n^{\prime} c} * Q_{n c}\right)
$$

where $V$ is the total value of all crop production by a household $n, P$ is the farm-gate sale price of crop $c$ that household $n$ reported, and $Q$ is the quantity of $c$ that household $n$ reported producing. Where a household did not report selling any portion of $Q_{c}$, and so did not report a farm-gate sale price, $P$ is the average of the prices reported by all other households that did report selling a portion of $Q_{c}$. 
The aim of this constructed variable is to provide a proxy to account for the loss or gain a household would receive from carrying out the environmental condition, and in the final model it is interacted with the condition attribute. Crop value is a complex variable that includes information about factors such as amount of land, productivity of land, availability of inputs to production, a household's knowledge of and ability to farm, and the market price that a household could receive for crops. Where crop value is low, these underlying variables are likely to be smaller, indicating a greater opportunity cost and a lower chance of profiting from the agroforestry condition. Where crop value is high, however, it indicates that one or more of these underlying variables are higher and the household's opportunity cost of the condition is lower, and in many cases even negative (i.e. a gain from the condition). It is expected that households will have a negative preference for the condition overall, but that households with high crop value will have a less negative preference.

\section{MODEL RESULTS AND POST-ESTIMATION ANALYSIS}

(a) Descriptive statistics

The average respondent was male, ${ }^{\mathrm{ix}} 50$ years old, and with 5.7 years of education, corresponding to primary school in Ecuador. Their household included 2.4 adults and 1.3 children ( $<18$ years of age). Regarding land, $63.8 \%$ of households claimed legal title to a portion of their land. On average, households claimed some form of tenure over 15.4 hectares of land, 3.6 of which was set aside for cultivation and 6.1 of which was actively used for pastureland. A summary of these descriptive statistics and comparison to data from censuses or other studies is provided in Table 5. The median (mean) annual gross cash income for 2010 was $\$ 4,014(\$ 6,736)$ and the median (mean) portion of that income from crops was $63 \%(55.5 \%) .{ }^{\mathrm{x}}$ No data was identified with which to compare household income.

TABLE 5 ABOUT HERE 
In relation to agroforestry, $63 \%$ of respondents stated they understood what agroforestry was before an explanation was given. After that explanation, $90 \%$ of respondents reported preferring agroforestry to traditional agriculture and $57 \%$ stated an economic reason why they believed agroforestry was better. The primary reason given was that agroforestry incorporates a diversity of crops that helps smooth production and income over the year. All households believed agroforestry to be more environmentally friendly. On average, each household had 1.4 Ha of land under a use that could be considered agroforestry, but if lending was available and affordable, they would on average like to convert an additional $2.9 \mathrm{Ha}$, with the greatest demand for silvopasture at $1.7 \mathrm{Ha}$.

(b) Model results

Results from three mixed logit models are presented in Table 6. The first model includes only the attributes of the CE and estimates their coefficients as random parameters, the second is the same as the first, but also includes interaction terms. The third model includes the interaction terms, but only models the alternative attributes as random parameters if their standard distribution entered significantly into model 2.

\section{TABLE 6 ABOUT HERE}

The results confirm that there is demand for credit as indicated by the positive and significant coefficient for the loan dummy variable. Importantly, the parameter for loan is modeled as random to account for unobserved characteristics of respondents that would influence their preferences related to borrowing. Some of that heterogeneity is observed in the interaction of loan and the number of children in a household. The more children, the greater the probability a household will demand a loan. That is likely because these households have a longer time horizon for investment and include more individuals able to work to help ensure the loan is repaid.

In contrast, the environmental condition has a negative association with choice of an alternative. Without considering interactions (Model 1), preference heterogeneity for the condition is observed: 
although the population mean is not statistically different from zero, the standard deviation is. In Models 2 and 3, an interaction of the condition and the natural logarithm of the value of a household's crop production was introduced, to account for the potential opportunity cost or gain associated with meeting the condition. It reveals that the mean main effect of the condition on choice of alternative is negative, and that households with higher crop value demonstrated a less negative, and possibly positive preference for the condition. The result it predicts is intuitive, but it is important to empirically show that the uptake of CB-PES will depend on a household's predicted cost or gain associated with the environmental condition proposed.

Finally, interest rate has a negative association with the respondents' choice of alternative. As is expected and common in CEs, respondents demonstrate a negative utility for the attribute associated with them making a payment. It is highly unlikely that any respondent would demonstrate a positive utility for interest rate, so the random parameter for this attribute is specified in the model to include that assumption. Following common practice, this was done by multiplying the variable by negative one and then modeling it using a lognormal distribution (Hensher, Rose, \& Greene, 2005). That negative transformation is reversed for all post-estimation analysis.

(c) Welfare change associated with environmental conditionality

The choice experiment method is consistent with utility maximization and demand theory, so when the parameter estimates of the model are obtained, welfare measures can be obtained (Bateman et al., 2002). The marginal change in welfare of an attribute is usually expressed as a monetary value and found by taking the ratio of the coefficient of that attribute over the coefficient of a price attribute (Hoyos, 2010). Here, the same basic approach is applied to measure the welfare change associated with the attribute of the environmental condition, but uniquely and appropriately to the context, the valuation attribute used is annual interest rate of a loan. The resulting marginal willingness-to-pay (MWTP) can be interpreted as the increase or decrease in interest rate that a household would require in order to accept a change in the relevant loan terms. 
There are a number of specific approaches used to estimate the MWTP in a MXL model when one or more of the parameters is random (Sillano \& Ortúzar, 2005). The simplest and most common method is to use only the mean of the random parameters in any associated MWTP calculation. It is preferable to use all of the information associated with the random parameter and simulate the MWTP (Hensher et al., 2005), but that leads to estimates further from zero and with larger confidence intervals. Both methods were carried out and the results are presented in Table 7.

\section{TABLE 7 ABOUT HERE}

The most relevant portion of these results is the MWTP for the agroforestry condition $\left(\mathrm{MWTP}_{\mathrm{AFC}}\right)$. Although agroforestry may be more profitable in the sense that it increases cash flow per hectare, a household's decision to transition to agroforestry depends on a number of other considerations and potential opportunity costs. For example, to convert one hectare of land to agroforestry, a household with only a small area of land under tenure would forgo a larger proportion of their land available for subsistence food production compared to a household with more land. So although agroforestry may have a higher NPV based on cash flow analysis, the transition to agroforestry will be more or less desirable based on household characteristics. That broader idea is what is being considered when we discuss change in welfare associated with the condition, which is estimated as the MWTP for the condition. When that MWTP is negative, it implies that a household perceives its total costs of conversion to agroforestry as relatively high, so would require a relatively lower rate of repayment in credit in order to compensate for that.

The results indicate that, holding all else equal, the main effect of including the environmental condition is to lower the WTP for a loan by approximately $3 \%$ of the annual interest. That effect is reduced and potentially reversed by a positive MWTP associated with the interaction of condition and Ln(Crop value), such that for every unit increase on this scale, a household's WTP for a conditional loan increases by approximately $0.4 \%$ annual interest rate.

Understanding these population moments is very useful, but can disguise underlying complexity in the MWTP distribution. To fully explore the $\mathrm{MWTP}_{\mathrm{AFC}}$, another simulation was carried out that 1) jointly 
considered the main and interaction effects for the condition, and 2) used the sample population data for crop value to relate it to the case study. The results presented in Figure 4 show a more complex picture of $\mathrm{MWTP}_{\mathrm{AFC}}$ in this case study. It indicates the existence of three groups with varying levels of crop income and resulting $\mathrm{MWTP}_{\mathrm{AFC}}$. One group has high crop income and a positive $\mathrm{MWTP}_{\mathrm{AFC}}$ for the condition, one has lower crop income and a negative $\mathrm{MWTP}_{\mathrm{AFC}}$, and the final group has very little or no crop income and a large negative $\mathrm{MWTP}_{\mathrm{AFC}}$. The characterization of these groups is presented in Figure 4 and Table 8 . The overarching result, is that the majority of the population has a small positive or small negative $\mathrm{MWTP}_{\mathrm{AFC}}$, with an estimated small negative mean $\mathrm{MWTP}_{\mathrm{AFC}}$ across the entire population.

FIGURE 4 ABOUT HERE

TABLE 8 TO IMMEDIATELY FOLLOW FIGURE 4

(d) Simulating demand

The predicted utility to each respondent of alternatives with specified attribute levels can be simulated based on the MXL coefficients, from which the rate of demand for conditional and unconditional loans can be estimated. The actual uptake of such loans will depend on a number of other factors, but simulating demand helps to understand households' preferences for and perceptions of these loans. Table 9 presents the estimated demand for a conditional, $\$ 2,500$, four-year loan where the reference market interest rate for unconditional loans is $12 \%$. That reference rate is the low-end of market rates in areas surrounding the case study area, but is presented here for illustrative purposes and deemed reasonable since it is assumed that measures to ensure credit repayment, such as joint liability or collateral requirements, would be put in place and permit this more reasonable rate.

\section{TABLE 9 ABOUT HERE}

Following the third row of Table 9 where the interest rate for a conditional loan is $8 \%$, we find that given this scenario, it is predicted that $56 \%$ of respondents would like to receive a conditional loan. 
Compared to a $12 \%$ market rate, the conditional $8 \%$ interest rate corresponds to a CB-PES payment of $\$ 68.28$ per year, which would be awarded as a decrease in the amount that the borrower had to repay each year of the loan as long as the environmental condition was being met.

During the simulations for predicted demand, each household's MWTP for the condition was also simulated (following the same approach as in Figure 4 and Table 8) as an estimate of that household's welfare change associated with accepting the agroforestry condition. Multiplying the probability of household $n$ accepting a conditional loan by their MWTP for the condition gives an expected change in welfare associated with the condition for each household, under the given loan conditions. The mean expected MWTP is presented in column five as a percentage of the CB-PES.

There are two key results revealed by Table 9. First, when the interest rate offered if the condition is met is $8 \%$, the CB-PES represents only $8.3 \%$ of the total annual loan repayment. Even at lower rates (thus larger CB-PES), the ES payment always represents a small portion of total loan repayment, meaning that under this scenario, households are willing to take on the majority of the financial burden of borrowing a conditional loan. That indicates that households do demand credit and providing it, even with an environmental condition, would be relieving a market constraint. The result aligns with the fact that the coefficient for a loan, irrespective of whether or not it is conditional, in the econometric model is positive and significant, indicating latent demand for credit.

Second, based on the expected household demand for conditional loans (i.e. assuming self-selecting participation in a CB-PES program) at an $8 \%$ interest rate, only $2.4 \%$ of the CB-PES represents compensation for the on-average negative marginal change in welfare a household anticipated to experience due to the agroforestry condition. That is, on average across the $56 \%$ of households demanding loans with these terms, only $\$ 1.66$ of the entire $\$ 68.28 \mathrm{CB}-\mathrm{PES}$ is compensation for an anticipated decrease in welfare associated with carrying out the environmental condition. For comparison, assuming non-self-selecting participation was feasible and implemented, the mean (negative) $\mathrm{MWTP}_{\mathrm{AFC}}$ across the entire population could be covered by only $6.6 \%$ of the CB-PES under this scenario. That is 3 -fold higher than a self-selecting scenario, but still only a small portion of the 
CB-PES. The general result is the same for all scenarios simulated: only a small portion of the CB-PES would be compensation for the opportunity costs of meeting the agroforestry condition.

A final key consideration is to look further at the debt burden that households are hypothetically being asked to accept if they participate. Table 10 compares the annual repayment that a household would be liable for with conditional loan interest rates ranging from $12 \%$ to $0 \%$. The liability is expressed in both \$/year and as a percentage of gross cash income reported for the 12-month period prior to the survey being implemented. The percentage does not account for the entire population, but is a mean expected value representing only the portion of the population that it is predicted would demand conditional loans with the given loan terms.

\section{TABLE 10 ABOUT HERE}

It is difficult from this data to say what an acceptable level of liability is, but an annual repayment of $20-30 \%$ of annual income is reasonable compared to microcredit examples in other countries where smaller loans (on the scale of $\$ 100$ 's, rather than $\$ 1,000 \mathrm{~s}$ ) are taken out and repaid multiple times a year in communities with lower average annual income than this case study (Collins, Morduch, Rutherford, \& Ruthven, 2009). More importantly, the increase in liability if the CB-PES condition is not met, is not very large for all reasonable scenarios. If a household were deemed able to handle the liability in the first place, then the change associated with the undesirable outcome of not meeting the conditionality generally represents only a few percent of gross annual income. As such, the surprise liability if the condition were not met does not appear overly burdensome relative to the total liability a household would be accepting.

\section{DISCUSSION}

(a) Summary of case study 
The Intag Zone represents a credit-constrained context where it is believed that increasing the use of agroforestry helps save the forested area that remains, provides increasing levels of biodiversity and ES on agricultural land, and supports adaptation to climate change. The above results indicate that if CBPES were implemented, where the magnitude of payment is approximately $\$ 70$ per hectare per year with a condition of converting one hectare of land to agroforestry, more than half of households would be interested in accepting conditional loans of $\$ 2,500$ paid back over four years. A payment of that size is in line with other case studies in Latin America. ${ }^{\text {xi }}$ For example, a case study of implementing the World Bank’s RISEMP in Nicaragua, reported a maximum PES of \$75/ha/yr over 4 years (Pagiola et al., 2007). In Costa Rica, the national PES program paid $\$ 1.30 /$ tree in an agroforestry system, spread over three years (FONAFIFO, 2009); when the same terms are applied to the cash flow models of a mixed agroforestry system in Intag (Table 2) it equates to an average $\$ 100 /$ ha/yr over the first five years. Most interestingly, under these CB-PES conditions, the participating households are willing to accept over $90 \%$ of the loan repayment burden and only $2.4 \%$ of the CB-PES compensates for the negative average welfare change associated with meeting the agroforestry condition.

(b) CB-PES as incentive

The case of Intag does not allow a direct comparison between CB-PES and more conventional cash PES, but it does illustrate some key points about CB-PES as an incentive. By incorporating strong conditionality into credit provision, CB-PES explicitly links the dual objectives of overcoming market constraints and providing a relatively direct reward for the provision of ES. It is inherently designed to support both environment and development objectives, rather than create trade-offs, which is something that all stakeholders should prefer.

The key empirical result is that CB-PES fits key criteria of a good incentive highlighted in other studies. The results indicate that under any reasonable scenario, potential ES providers are willing to take on the majority of the burden of a conditional loan repayment and only a small proportion of the CB-PES reward is considered compensation for meeting the environmental condition. CB-PES is thus an incentive that potential ES providers would perceive as supportive, rather than controlling (Frey \& 
Jegen, 2001). Related to that, CB-PES fits the paradigms of PES as co-investment (van Noordwijk \& Leimona, 2010) or a more reciprocal arrangement (Farley \& Costanza, 2010) that many PES academics and practitioners consider the best ways to frame PES, particularly in a developing country context, and especially in Latin America.

It is recognized that the case study presented here was where the condition aligned with a broad agenda in the area, the increase of agroforestry. Nonetheless, even for households that are expected to have a negative welfare change associated with agroforestry, the results hold. When the interest rates of conditional loans are so low that it is estimated that nearly $90 \%$ of the households would demand them, those households would have to accept $75 \%$ of the loan repayment and the compensatory portion of CB-PES would continue to only represent a small portion of the reward. In effect, the CB-PES would be primarily working to make borrowing more affordable instead of compensating for opportunity costs of the environmental condition.

Further, because the reward is time constrained and is really a reward that lowers a burden, rather than increases a payment, it is less likely to induce long term shifts in endogenous preferences. In practice, this would reduce the risk of entitlement among ES providers, which is a concern of direct cash PES highlighted by ecological and institutional economists (Farley \& Costanza, 2010; Vatn, 2010).

(c) Implementing CB-PES

The results also highlight considerations for implementing CB-PES. ${ }^{\text {xii }}$ First, both the cost to the ES buyer and demand for conditional loans of the ES provider are sensitive to the reference market interest rate. A higher reference rate implies a greater demand for the conditional loan at any given interest rate; if the unconditional reference rate is higher, households will have a greater willingness to accept the environmental condition in order to receive a lower interest rate. Any organization wanting to implement CB-PES would need to determine what the appropriate and/or feasible reference rate for loans is before being able to understand the cost of such a program and willingness of households to accept conditional loans. 
The results also illustrate that the demand of an individual household for a conditional loan is dependent on their expected loss or gain associated with carrying out the environmental condition. As is the case with any voluntary incentive policy there is a self-selection bias, where households that anticipate a low opportunity cost or even a gain associated with the condition are more likely to participate. Targeting may be required to improve the environmental performance of CB-PES, as is true with PES broadly (Wünscher, Engel, \& Wunder, 2008). That would change the cost of the program and require heterogeneous contracts to achieve optimal cost-effectiveness, but the results related to acceptance of repayment burden and only a small portion of CB-PES being compensatory would hold. That is demonstrated in Table 9, where the compensatory portion of CB-PES is assessed over the entire sample and not just the households that would self-select to participate under specific conditions. Further, the variation in the anticipated cost or gain of meeting the condition provides a second reason specific to CB-PES for preferring heterogeneous contracts. With variation in the MWTP for an environmental condition, heterogeneous contracts would permit cross-subsidization between borrowers, reducing the total current cost to the ES buyer. Doing so would help maintain the level of capital available for lending, bringing the mechanism closer to being self-financing once capitalized.

Additionally, access to affordable credit is considered a development issue and CB-PES is an incentive mechanism with dual environment and development objectives. If the proposed reward is large, more households will be interested in accepting conditional loans with the reported intent of meeting the condition, but there is concern over whether they would be able to pay back the loan at the higher reference rate if the condition is not met. In the case study here, the level of payback appears reasonable, but safeguards would nonetheless need to be in place to ensure no household is taking on an unacceptable level of debt. Further, to be supportive of lower-income households participating in CB-PES, the reward may be better constructed as a partially conditional reward. For example, if the reward were a reduction in annual repayments of $\$ 100$, perhaps $\$ 50$ would be unconditional and reward the attempt to meet the condition, while $\$ 50$ would be conditional. Put another way, $\$ 50$ could be considered paying for the development benefit of access to affordable credit, while $\$ 50$ could be considered paying for the delivery of ES. If multiple donors with these different objectives could work 
together, that approach could both 1) reduce the interest rate lower than the budget constraint of the ES buyer, and 2) reduce the surprise burden if the environment condition is not met.

Finally, only one institutional factor entered the model, but is worth noting: land title. Respondents with legal title to at least some portion of their land had a lower utility for longer-term loans than those without any legal title, which indicates titled households are more willing to accept shorter loan periods. A shorter period requires higher annual repayments, but lowers the overall cost of financing. That in turn leads to a lower CB-PES. Land titling could also make CB-PES more feasible, particularly if a normal lender was providing the loan, and the CB-PES was paid by a third party interested in public good outcomes. An evaluation of a pilot project by the Inter-American Development Bank (IDB) to improve land titling in Ecuador found that improved land titling permitted agriculturalists greater access to credit, and a larger-scale project is now underway (IDB, 2013). Overall, it appears that improved land tenure could make CB-PES more feasible and cheaper to implement.

\section{SUMMARY}

This study proposes and ex-ante assesses the novel incentive of CB-PES. It is found to be a promising form of PES that combines a performance reward with a reduction in credit constraints, and in doing so fits key criteria that are believed to make for good incentives and are increasingly discussed in the PES literature. The broader dynamics and key considerations for implementing CB-PES are also observed. In terms of design, the uptake of conditional loans and cost of CB-PES will depend greatly on the reference market interest rate and the expected loss or gain associated with the environmental conditionality. In terms of implementation, particular attention should be paid to the debt burden a potential ES provider may be attempting to take on; heterogeneous contracts could be highly beneficial; there is a case for both environmental and development benefits to be jointly financed through a credit-based reward; and improved land tenure could make CB-PES more feasible and cheaper to implement. 
The case study was chosen as one where negative environmental trends need to be reversed and market constraints relieved to ensure sustainable development of the area. It is a context that is prevalent throughout developing countries and so our results are widely relevant. Based on those results, it is wholly recommended that the CB-PES be explored further and piloted beyond the few examples of convertible lending that, notably, have reported success. 


\section{REFERENCES}

Agimass, F., \& Mekonnen, A. (2011). Low-income fishermen's willingness-to-pay for fisheries and watershed management: An application of choice experiment to Lake Tana, Ethiopia. Ecological Economics, 71(0), 162-170. doi:http://dx.doi.org/10.1016/j.ecolecon.2011.08.025

Allet, M. (2011). Measuring the environmental performance of microfinance (CEB Working Paper No. 11/045). Brussels, Belgium: Centre Emile Bernheim, Solvay Brussels School of Economics and Management, Université Libre de Bruxelles. Retrieved from http://www.cermi.eu/working-papers.php

Anderson, C. L., Locker, L., \& Nugent, R. (2002). Microcredit, social capital, and common pool resources. World Development, 30(1), 95-105. doi:10.1016/So305750X(01)00096-1

Arisman, C. (2012). A preliminary study of scaling-up agroecology in the Intag Region of Ecuador (Undergraduate Honors Research Thesis). University of Vermont, Burlington, VT.

Assunção, J., Gandour, C., Rocha, R., \& Rocha, R. (2013). Does Credit Affect Deforestation?: Evidence from a Rural Credit Policy in the Brazilian Amazon (CPI Technical Report). Rio de Janiero: Núcleo de Avaliação de Políticas Climáticas da Pontifícia Universidade Católica do Rio de Janeiro (NAPC/PUC-Rio) \& Climate Policy Initiative Rio de Janeiro (CPI Rio). Retrieved from http://climatepolicyinitiative.org/publication/does-credit-affect-deforestationevidence-from-a-rural-credit-policy-in-the-brazilian-amazon/

Atkinson, G., Bateman, I., \& Mourato, S. (2012). Recent advances in the valuation of ecosystem services and biodiversity. Oxford Review of Economic Policy, 28(1), 2247. doi:10.1093/oxrep/grsoo7

Barr, R., \& Mourato, S. (2012). Investigating fishers' preferences for the design of marine payments for ecosystem services schemes (Working Paper No. 101). London, UK: Grantham Research Institute on Climate Change and the Environment. Retrieved from 
http://www.lse.ac.uk/GranthamInstitute/publications/WorkingPapers/Abstracts/10 o-109/fishers-marine-payments-environmental-services-schemes.aspx

Bateman, I. J., Carson, R. T., Day, B., Hanemann, W. M., Hanley, N., Hett, T., ... Swanson, S. (2002). Economic Valuation With Stated Preference Techniques: A Manual. Cheltenham, UK: Edward Elgar.

Beharry-Borg, N., \& Scarpa, R. (2010). Valuing quality changes in Caribbean coastal waters for heterogeneous beach visitors. Ecological Economics, 69(5), 1124-1139. doi:http://dx.doi.org/10.1016/j.ecolecon.2009.12.007

Bénabou, R., \& Tirole, J. (2003). Intrinsic and extrinsic motivation. Review of Economic Studies, 7o(3), 489-520. doi:10.1111/1467-937X.00253

Bénabou, R., \& Tirole, J. (2006). Incentives and prosocial behavior. American Economic Review, 96, 1652-1678. doi:10.1257/aer.96.5.1652

Bennett, G., Carroll, N., \& Hamilton, K. (2013). Charting new waters: State of watershed payments 2012. Washington, DC: Ecosystem Marketplace. Retrieved from http://www.forest-trends.org/dir/iwstypes/

Blackman, A., Albers, H., Ẫvalos-Sartorio, B., \& Crooks, L. (2005). Deforestation and shade coffee in Oaxaca, Mexico: Key research findings (Discussion Paper No. 05-39). Washington, DC: Resources for the Future. Retrieved from http://www.rff.org/documents/RFF-DP-05-39.pdf

Bowles, S. (2008). Policies designed for self-interested citizens may undermine "the moral sentiments": Evidence from economic experiments. Science, 320(5883), 1605-1609. doi:10.1126/science.1152110

Boyd, J. H., \& Mellman, R. E. (1980). The effect of fuel economy standards on the U.S. automotive market: An hedonic demand analysis. Transportation Research Part A: General, 14(5-6), 367-378. doi:http://dx.doi.org/10.1016/o191-2607(80)90055-2

Brey, R., Riera, P., \& Mogas, J. (2007). Estimation of forest values using choice modeling: An application to Spanish forests. Ecological Economics, 64(2), 305-312. doi:http://dx.doi.org/10.1016/j.ecolecon.2007.07.006

Bubb, P., May, I., Miles, L., \& Sayer, J. (2004). Cloud forest agenda. Cambridge, UK: UNEPWCMC. Retrieved from http://www.unepwcmc.org/medialibrary/2010/o9/10/a7c88b36/Cloud_Forest.pdf 
Cardell, N. S., \& Dunbar, F. C. (1980). Measuring the societal impacts of automobile downsizing. Transportation Research Part A: General, 14(5-6), 423-434. doi:http://dx.doi.org/10.1016/0191-2607(80)90060-6

Cardenas, J. C., Stranlund, J., \& Willis, C. (2000). Local environmental control and institutional crowding-out. World Development, 28(10), 1719-1733. doi:http://dx.doi.org/10.1016/So305-750X(oo)0oo55-3

Carlsson, F., Frykblom, P., \& Liljenstolpe, C. (2003). Valuing wetland attributes: an application of choice experiments. Ecological Economics, 47(1), 95-103. doi:http://dx.doi.org/10.1016/j.ecolecon.2002.09.003

Choi, A. S., Ritchie, B. W., Papandrea, F., \& Bennett, J. (2010). Economic valuation of cultural heritage sites: A choice modeling approach. Tourism Management, 31(2), 213-220. doi:http://dx.doi.org/10.1016/j.tourman.2009.02.014

Christensen, T., Pedersen, A. B., Nielsen, H. O., Mørkbak, M. R., Hasler, B., \& Denver, S. (2011). Determinants of farmers' willingness to participate in subsidy schemes for pesticide-free buffer zones-A choice experiment study. Ecological Economics, 7o(8), 1558-1564. doi:http://dx.doi.org/10.1016/j.ecolecon.2011.03.021

Collins, D., Morduch, J., Rutherford, S., \& Ruthven, O. (2009). Portfolios of the poor: How the world's poor live on \$2 a day (Hardback.). Princeton and Oxford: Princeton University Press.

Conservation International. (2013). About Verde Ventures. Retrieved from http://www.conservation.org/global/verdeventures/about/pages/default.aspx

Corbera, E., Soberanis, C. G., \& Brown, K. (2009). Institutional dimensions of payments for ecosystem services: An analysis of Mexico's carbon forestry programme. Ecological Economics, 68(3), 743-761. doi:10.1016/j.ecolecon.2008.06.008

Cranford, M., Cueva, J., \& Peck, M. (2010). Agroforestry in the Intag River Region of Ecuador. In Latin America and the Caribbean: A biodiversity superpower (pp. 69-71 of Chapter 6 “Agriculture”). New York, NY: United Nations Development Programme. Retrieved from http://web.undp.org/latinamerica/biodiversity\%2Dsuperpower/

Cranford, M., \& Mourato, S. (2011). Community conservation and a two-stage approach to payments for ecosystem services. Ecological Economics, 71(0), 89-98. doi:10.1016/j.ecolecon.2011.08.007 
Dachary-Bernard, J., \& Rambonilaza, T. (2012). Choice experiment, multiple programmes contingent valuation and landscape preferences: How can we support the land use decision making process? Land Use Policy, 29(4), 846-854. doi:http://dx.doi.org/10.1016/j.landusepol.2012.01.002

EcoEnterprises Fund. (2012). Investment Strategy. Retrieved from http://www.ecoenterprisesfund.com/

Espinosa-Goded, M., Barreiro-Hurlé, J., \& Ruto, E. (2010). What do farmers want from agri- environmental scheme design? A choice experiment approach. Journal of Agricultural Economics, 61(2), 259-273. doi:10.1111/j.1477-9552.2010.00244.x

FAO. (2010). Global Forest Resources Assessment 2010 (FAO Forestry Paper No. 163). Rome, Italy: Food and Agriculture Organization of the United Nations. Retrieved from http://www.fao.org/forestry/fra/fra2010/en/

Farley, J., \& Costanza, R. (2010). Payments for ecosystem services: From local to global. Ecological Economics, 69(11), 2060-2068. doi:10.1016/j.ecolecon.2010.06.010

Feder, G., \& Umali, D. L. (1993). The Adoption of Agricultural Innovations: A Review. Technological Forecasting and Social Change, 43(3-4), 215-239.

Fehse, J. (2012). Private conservation agreements support climate action: Ecuador's Socio Bosque programme. London, UK: Climate \& Development Knowledge Network. Retrieved from http://cdkn.org/resource/private-conservation-agreements-supportclimate-action-ecuadors-socio-bosque-programme/

Ferraro, P. J., \& Kiss, A. (2002). Direct payments to conserve biodiversity. Science, 298(5599), 1718 -1719. doi:10.1126/science.1078104

Ferraro, P. J., Lawlor, K., Mullan, K. L., \& Pattanayak, S. K. (2012). Forest Figures: Ecosystem Services Valuation and Policy Evaluation in Developing Countries. Review of Environmental Economics and Policy, 6(1), 20-44.

Ferraro, P. J., \& Simpson, R. D. (2002). The cost-effectiveness of conservation payments. Land Economics, 78(3), 339 -353. doi:10.3368/le.78.3.339

Ferrini, S., \& Scarpa, R. (2007). Designs with a priori information for nonmarket valuation with choice experiments: A Monte Carlo study. Journal of Environmental Economics and Management, 53(3), 342-363. doi:10.1016/j.jeem.2006.10.007 
FONAFIFO. (2009). Estadística PSA. Fondo Nacional de Financiamiento Forestal. Retrieved from http://www.fonafifo.com/paginas_espanol/servicios_ambientales/sa_estadisticas.ht $\mathrm{m}$

Frey, B. S., \& Jegen, R. (2001). Motivation crowding theory. Journal of Economic Surveys, 15(5), 589-611. doi:10.1111/1467-6419.00150

Gneezy, U., \& Rustichini, A. (2000). A fine is a price. The Journal of Legal Studies, 29(1), 117. doi:10.1086/468061

Greiber, T. (2009). Payments for Ecosystem Services: Legal and Institutional Frameworks (IUCN Environmental Policy and Law Paper No. 78). Gland, Switzerland: IUCN. Retrieved from http://data.iucn.org/dbtw-wpd/edocs/EPLP-o78.pdf

Groom, B., \& Palmer, C. (2009). Environmental services and poverty alleviation: either, or, or both? (Discussion Paper No. 46.2009). Department of Land Economics, University of Cambridge, Cambridge, UK. Retrieved from http://www.landecon.cam.ac.uk/RePEc/pdf/462009.pdf

Groom, B., \& Palmer, C. (2010). Cost-effective provision of environmental services: The role of relaxing market constraints. Environment and Development Economics, 15(02), 219-240. doi:10.1017/S1355770Xo9990167

Groom, B., \& Palmer, C. (2012). Relaxing constraints as a conservation policy (Nota di lavoro No. 2012.063). Fondazione Eni Enrico Mattei. Retrieved from http://www.feem.it/getpage.aspx?id=5038\&sez=Publications\&padre=73

Grosjean, P., \& Kontoleon, A. (2009). How sustainable are sustainable development programs? The case of the sloping land conversion program in China. World Development, 37(1), 268-285. doi:http://dx.doi.org/10.1016/j.worlddev.2008.05.003

Hensher, D. A., Rose, J. M., \& Greene, W. H. (2005). Applied choice analysis: A primer. Cambridge University Press.

HidroIntag. (2009). Hydroelectric generation system in the Intag River Basin for the conservation of water sources and for local development. Cotacachi, Ecuador: HidroIntag. 
Hole, A. R. (2007). Fitting mixed logit models by using maximum simulated likelihood. The Stata Journal, 7(3), 388-401.

Hoyos, D. (2010). The state of the art of environmental valuation with discrete choice experiments. Ecological Economics, 69(8), 1595-1603. doi:10.1016/j.ecolecon.2010.04.011

IDB. (2013). Land Titling and Access to Credit in Ecuador - Inter-American Development Bank. Inter-American Development Bank. Retrieved September 3, 2013, from http://www.iadb.org/en/news/webstories/2013-03-27/land-titling-and-access-tocredit-in-ecuador,10342.html

INEC. (2000). III Censo Nacional Agropecuario. Retrieved from http://servicios.agricultura.gob.ec/sinagap/index.php/censo-nacional-agropecuario

INEC. (2010). Censo de Población y Vivienda 2010. Retrieved from http://redatam.inec.gob.ec/

Kocian, M., Batker, D., \& Harrison-Cox, J. (2011). An Ecological Study of Ecuador's Intag Region: The Environmental Impacts and Potential Rewards of Mining. Tacoma, WA: Earth Economics. Retrieved from http://www.eartheconomics.org/FileLibrary/file/Reports/Latin\%20America/Final\% 20Intag\%20Report_lo_res.pdf

Mandel, J. T., Donlan, C. J., Wilcox, C., Cudney- Bueno, R., Pascoe, S., \& Tulchin, D. (2009). Debt investment as a tool for value transfer in biodiversity conservation. Conservation Letters, 2(5), 233-239. doi:10.1111/j.1755-263X.2009.00070.x Martin-Ortega, J., Ojea, E., \& Roux, C. (2012). Evidence-based understanding of Payments for Water Ecosystem Services: the Latin American experience. Presented at the 14th Annual BIOECON Conference: Resource Economics, Biodiversity Conservation and Development, Cambridge, UK.

Martinet, A. (2006). Diagnóstico AgroSocioEconomico de la microcuenca del Rio Cristopamba, Imbabura, Ecuador (Thesis). Montpellier, France: Centre international d'études supérieures en sciences agronomiques (Montpellier Sup Agro). Retrieved from https://web.supagro.inra.fr/pmb/opac_css/index.php?lvl=notice_display\&id=62699 
McFadden, D., \& Train, K. (2000). Mixed MNL models for discrete response. Journal of Applied Econometrics, 15(5), 447-470. doi:10.1002/10991255(200009/10)15:5<447::AID-JAE570>3.0.CO;2-1

McNeely, J. A., Faith, D. P., \& Albers, H. J. (2005). Biodiversity. In Part III: Policy responses. Millenium Ecosystem Assessment.

Mecham, J. (2009). Progress of the Paso Alto Project, the Southern Choco-Andean Corridor. In Rainforest Review Spring 2009 (p. 19). London, UK: Rainforest Concern. Retrieved from http://www.rainforestconcern.org/files/Rainforest_Review_2009.pdf

Mercer, D. E. (2004). Adoption of agroforesty innovations in the tropics: A review. Agroforestry Systems, 61-62(1-3), 311-328.

Muradian, R., Corbera, E., Pascual, U., Kosoy, N., \& May, P. H. (2010). Reconciling theory and practice: An alternative conceptual framework for understanding payments for environmental services. Ecological Economics, 69(6), 1202-1208. doi:10.1016/j.ecolecon.2009.11.006

Nair, P. K. R. (1993). An Introduction to Agroforestry. Dordrecht, The Netherlands: Kluwer Academic Publishers and the International Centre for Research in Agroforestry. Retrieved from http://www.worldagroforestry.org/units/Library/Books/PDFs/32_An_introduction _to_agroforestry.pdf?n=161

Narloch, U., Pascual, U., \& Drucker, A. G. (2012). Collective action dynamics under external rewards: Experimental insights from Andean farming communities. World Development, 40(10), 2096-2107. doi:http://dx.doi.org/10.1016/j.worlddev.2012.03.014

Orme, B. (1998). Sample Size Issues for Conjoint Anlaysis Studies (Sawtooth Software Technical Paper). Sequim, Washington: Sawtooth Software.

Pagiola, S. (2008). Payments for environmental services in Costa Rica. Ecological Economics, 65(4), 712-724. doi:http://dx.doi.org/10.1016/j.ecolecon.2007.07.033

Pagiola, S., Ramírez, E., Gobbi, J., de Haan, C., Ibrahim, M., Murgueitio, E., \& Ruíz, J. P. (2007). Paying for the environmental services of silvopastoral practices in Nicaragua. Ecological Economics, 64(2), 374-385. doi:10.1016/j.ecolecon.2007.04.014 
Pagiola, S., Rios, A., \& Arcenas, A. (2010). Poor household participation in payments for environmental services: Lessons from the Silvopastoral Project in Quindío, Colombia. Environmental and Resource Economics, 47(3), 371-394.

Pattanayak, S.K., Mercer, D. E., Sills, E., \& Yang, J.-C. (2003). Taking stock of agroforestry adoption studies. Agroforestry Systems, 57(3), 173-186.

Pattanayak, Subhrendu K., Wunder, S., \& Ferraro, P. J. (2010). Show Me the Money: Do Payments Supply Environmental Services in Developing Countries? Review of Environmental Economics and Policy, 4(2), 254-274.

Peck, M. (2009). Establishing a baseline: Determining deforestation rates in NW Ecuador using LANDSAT satellite imagery. London, UK: Rainforest Concern.

Peters-Stanley, M., Gonzalez, G., \& Yin, D. (2013). Covering New Ground: State of the Forest Carbon Markets 2013. Washington, DC: Ecosystem Marketplace.

Peters-Stanley, M., Hamilton, K., \& Yin, D. (2012). Leveraging the Landscape: State of the Forest Carbon Markets 2012. Washington, DC: Forest Trends. Retrieved from http://www.forest-trends.org/publication_details.php?publicationID=3242

Proyecto CAMBio. (2013). Descripción del Proyecto. Retrieved from http://www.proyectocambio.org/categoria_1330722483

Qin, P., Carlsson, F., \& Xu, J. (2011). Forest tenure reform in China: A choice experiment on farmers' property rights preferences. Land Economics, 87(3), $473-487$.

Rose, J. M., \& Bliemer, M. C. J. (2008). Stated preference experimental design strategies. In Handbook of Transport Modelling (pp. 151-180 (Chapter 8)). Oxford, UK: Elsevier.

Ruto, E., \& Garrod, G. (2009). Investigating farmers' preferences for the design of agrienvironment schemes: a choice experiment approach. Journal of Environmental Planning and Management, 52(5), 631-647. doi:10.1080/09640560902958172

Senaratna Sellamuttu, S., de Silva, S., Nguyen Khoa, S., \& Samarakoon, J. (2008). Good practices and lessons learned in integrating ecosystem conservation and poverty reduction objectives in wetlands. International Water Management Institute, Wetlands International. Retrieved from www.ramsar.org/pdf/wn/w.n.iwmi_poverty_report.pdf 
Shively, G. E. (2001). Poverty, consumption risk, and soil conservation. Journal of Development Economics, 65(2), 267-290. doi:http://dx.doi.org/10.1016/So3043878(01)o0137-7

Sillano, M., \& Ortúzar, J. D. de. (2005). Willingness-to-pay estimation with mixed logit models: some new evidence. Environment and Planning A, 37(3), 525 - 550. doi:10.1068/a36137

Smith, N., Dubois, J., Current, D., Lutz, E., \& Clement, C. (1998). Agroforestry experiences in the Brazilian Amazon: Constraints and opportunities. Brasilia, Brazil: The Pilot Program to Conserve the Brazilian Rainforest. Retrieved from http://documentos.bancomundial.org/curated/es/1998/o1/438750/agroforestryexperiences-brazilian-amazon-constraints-opportunities

Sommerville, M. M., Jones, J. P. G., \& Milner-Gulland, E. J. (2009). A revised conceptual framework for payments for environmental services. Ecology and Society, 14(2), 34.

Sunding, D., \& Zilberman, D. (2001). Chapter 4 The agricultural innovation process: Research and technology adoption in a changing agricultural sector. In Bruce L. Gardner and Gordon C. Rausser (Ed.), Handbook of Agricultural Economics (Vol. Volume 1, Part A, pp. 207-261). Elsevier. Retrieved from http://www.sciencedirect.com/science/article/pii/S1574007201100071

Tacconi, L. (2012). Redefining payments for environmental services. Ecological Economics, 73(0), 29-36. doi:10.1016/j.ecolecon.2011.09.028

Train, K. (1998). Recreation demand models with taste differences over people. Land Economics, 74(2), 230-239.

Train, K. (2009). Discrete choice methods with simulation (2nd ed.). Cambridge University Press.

Van Eijk, P., \& Kumar, R. (2009). Bio-rights in theory and practice: A financing mechanism for linking poverty alleviation and environmental conservation. Wageningen, The Netherlands: Wetlands International. Retrieved from http://www.wetlands.org/LinkClick.aspx?fileticket=ZBoKC4oOYew\%3D\&tabid=56

Van Noordwijk, M., \& Leimona, B. (2010). Principles for fairness and efficiency in enhancing environmental services in Asia: payments, compensation, or co-investment? Ecology and Society, 15(4), 17. 
Vatn, A. (2010). An institutional analysis of payments for environmental services. Ecological Economics, 69(6), 1245-1252. doi:10.1016/j.ecolecon.2009.11.018

Vohs, K. D., Mead, N. L., \& Goode, M. R. (2006). The psychological consequences of money. Science, 314(5802), 1154 -1156. doi:10.1126/science.1132491

Vollan, B. (2008). Socio-ecological explanations for crowding-out effects from economic field experiments in southern Africa. Ecological Economics, 67(4), 560-573. doi:http://dx.doi.org/10.1016/j.ecolecon.2008.01.015

Wetlands International. (2009). Planting trees to eat fish: Field experiences in wetlands and poverty reduction. Wageningen, The Netherlands: Wetlands International. Retrieved from

http://www.wetlands.org/WatchRead/tabid/56/mod/1570/articleType/ArticleView/ articleId/2296/Planting-trees-to-eat-fish.aspx

Wunder, S. (1996). Deforestation and the uses of wood in the Ecuadorian Andes. Mountain Research and Development, 16(4), 367-382.

Wunder, S. (2005). Payments for ecosystem services: Some nuts and bolts (Occasional Paper No. 42). Jakarta: Center for International Forestry Research. Retrieved from http://www.cifor.org/publications/pdf_files/OccPapers/OP-42.pdf

Wunder, S., \& Albán, M. (2008). Decentralized payments for environmental services: The cases of Pimampiro and PROFAFOR in Ecuador. Ecological Economics, 65(4), 685698. doi:10.1016/j.ecolecon.2007.11.004

Wünscher, T., Engel, S., \& Wunder, S. (2008). Spatial targeting of payments for environmental services: A tool for boosting conservation benefits. Ecological Economics, 65(4), 822-833. doi:10.1016/j.ecolecon.2007.11.014

Yuhe, G., \& Yi, D. (2000). Establishment and Operation of Community Trust Funds at Caohai. In Community-based Conservation and Development: Strategies and Practice at Caohai. China: Guizhou Nationalities Publishing House. Retrieved from https://www.savingcranes.org/chinaprogram_publications.html 
i Bennett, Carroll, \& Hamilton (2013) tracked 205 active incentive-based programs for watershed protection in 29 countries during 2011, with 76 more in development. One hundred and seventeen of the active programs and 54 of those in development are located in Latin America, Asia and Africa. Focusing on Latin America, evidence indicates a significant uptake of PES in the region. Martin-Ortega, Ojea, \& Roux (2012) reviewed publications from the last 10 years (since 2003) and identified 40 payments for watershed services (PWS) programs in Latin America. Similarly, Peters-Stanley, Hamilton, \& Yin (2012) tracked forest carbon projects in 2011 and found that Latin America captured the greatest market share by volume (30\%) and value (31\%). In 2012, production of forest carbon credits increased in other regions, but Latin America still captured the second greatest market share by volume (22\%) the largest by value (23\%) (Peters-Stanley, Gonzalez, \& Yin, 2013)

${ }^{\text {ii }}$ As indicated by the climate scenarios in 'Proyecto de Adaptación al Cambio Climático a traves de una Efectiva Gobernabilidad del Agua en el Ecuador (PACC),' http://www.pacc-ecuador.org/.

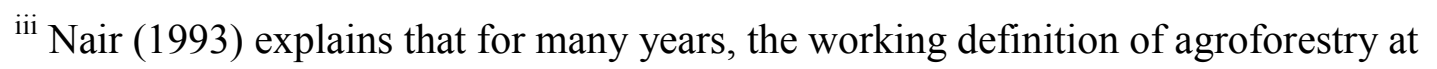
the International Centre for Research in Agroforestry (ICRAF) was "land-use systems and technologies where woody perennials (trees, shrubs, palms, bamboos, etc.) are deliberately used on the same land-management units as agricultural crops and/or animals, in some form of spatial arrangement or temporal sequence.” (pg. 14). ICRAF is now also known as the World Agroforestry Centre, and on its website presents a broad definition of agroforestry as simply "integrating trees into agriculturally productive landscapes".

iv The annual repayment amount shown on the choice card and throughout this paper always assumes a normal amortizing loan.

${ }^{v}$ The extension workers implementing the survey were permitted to discuss the costs of agroforestry with any respondent that required it. It is assumed that respondents that had previous experience with agroforestry or knowledge of it (63\% said they understood what agroforestry was) would have reasonable knowledge of the costs associated with conversion to agroforestry practices. 
${ }^{v i}$ The levels of a given attribute are qualitatively coded in rank order (e.g. 1, 2, 3 for an attribute with three levels). Each attribute is shifted one level up, where if the top level is reached, on the next shift the level returns to 1.

vii The idea of a "community" in this case refers to any named collection of households. Some are large villages, others are a small collection of houses.

${ }^{\text {viii }}$ A MNL was also estimated for this data and the results agree with those of the MXL: the sign of the MNL parameters are all the same as the sign of the mean of the parameter in the MXL. Additionally, all interactions included in the MXL were significant to at least $90 \%$ in the MNL.

ix The survey implementers were instructed to try and speak with male heads of households, who have the most say over household and land-use decisions.

${ }^{\mathrm{x}}$ The most prevalent source of non-farm income was still related to agricultural practices in the region: $57 \%$ of households reported that one or more household members earned income by providing manual labor on other households' farming land.

${ }^{x i}$ No comparable case studies were identified of PES for agroforestry actions in Ecuador. For reference, however, one case of PES for reforestation in Ecuador paid approximately $\$ 40-\$ 60$ per hectare annualized over 3 years (Wunder \& Albán, 2008) and the country's national program for forest conservation, Socio Bosque, pays $\$ 30 /$ ha/yr for the first 50 hectares of forest cover under contract (Fehse, 2012).

${ }^{\text {xii }}$ In addition to the considerations for implementation that arise from the analysis here, various other implementation issues would need to be considered. For example, monitoring and enforcement would need to be addressed. 


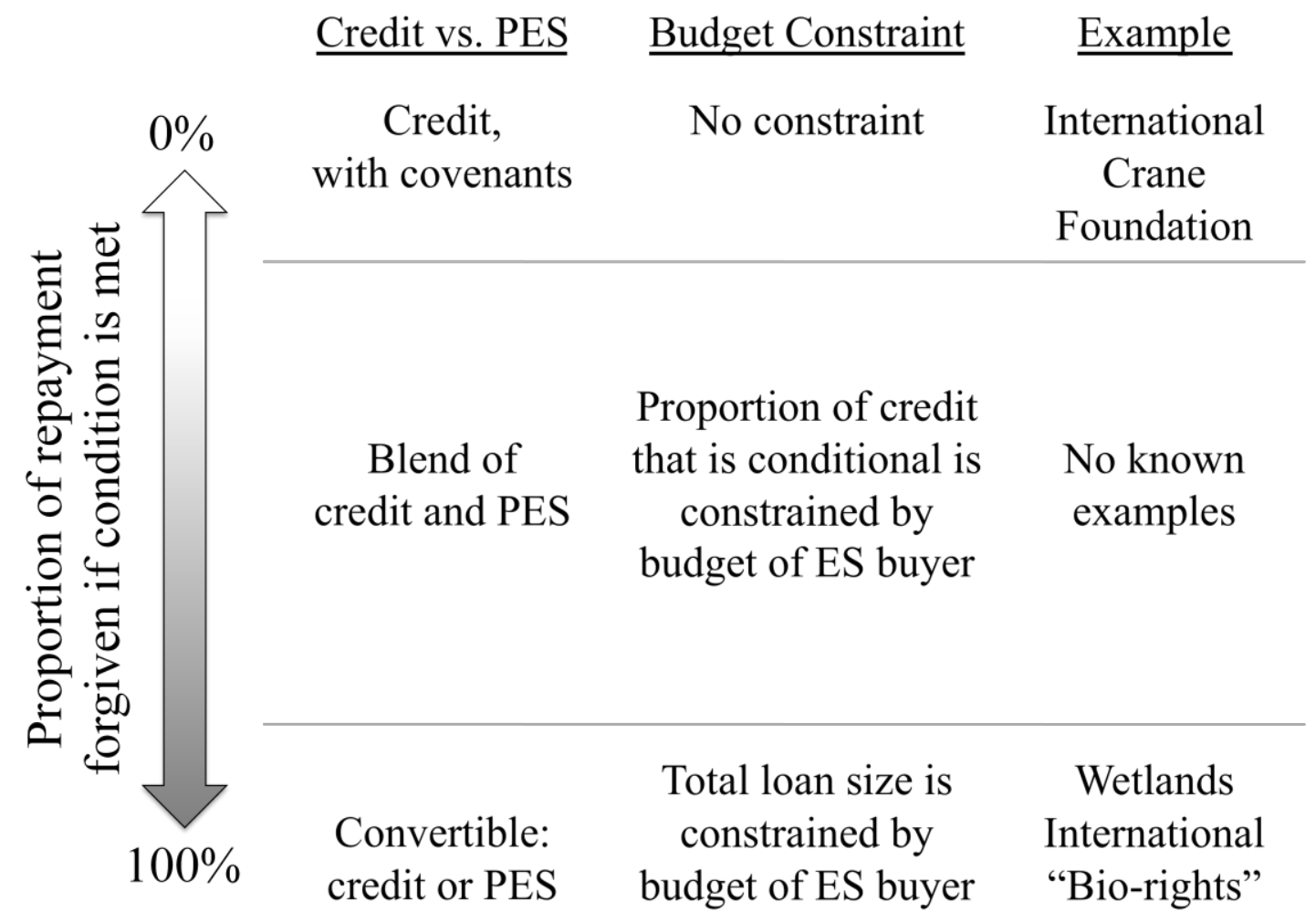

Figure 1: Conceptualizing credit-based payments for ecosystem services (CB-PES). 

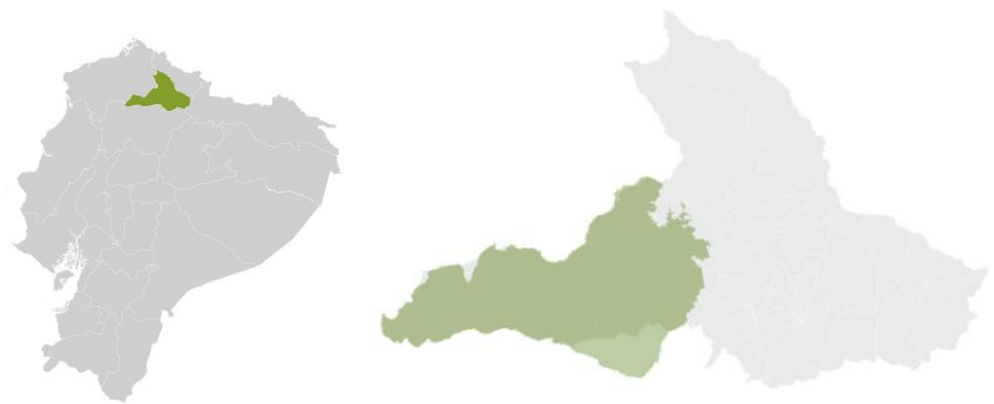

Figure 2: Map of Ecuador (left) indicating the location of Imbabura Province, and map of Imbabura Province (right) with the ecological boundary of Intag-Manduriacos ecological zone overlaid. Light green on the map of Imbabura (right) indicates the areas where the ecological zone reaches outside of the political boundary. The zone is often referred to simply as Intag, because the vast majority of the population in this area lives in the Intag River Watershed, which approximately comprises the Eastern half of the ecological zone. Following that convention, we refer to the entire ecological zone as Intag. Maps reproduced with permission from Kocian et al. (2011). 


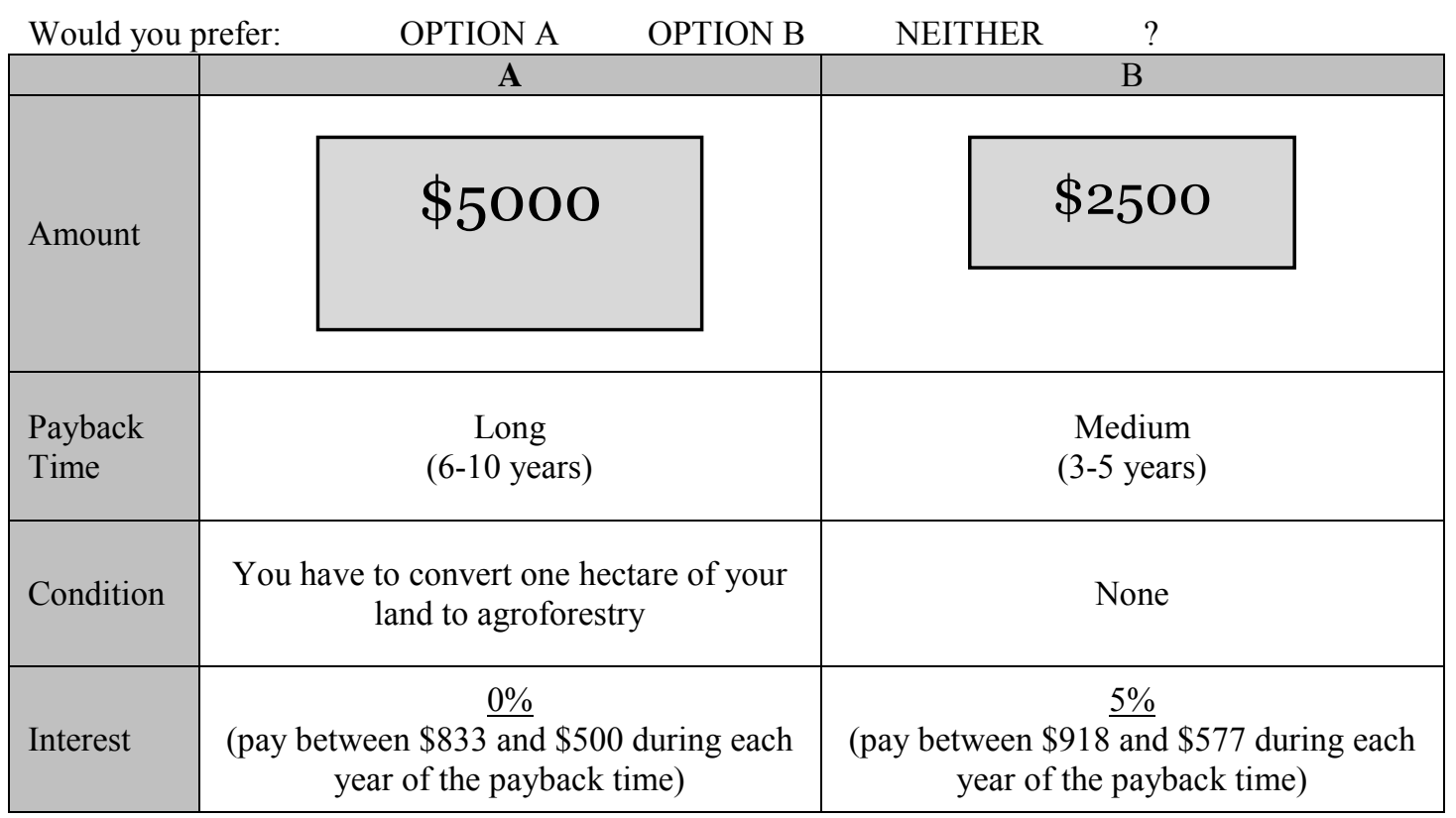

Figure 3: Example of choice card in CE for CB-PES. 


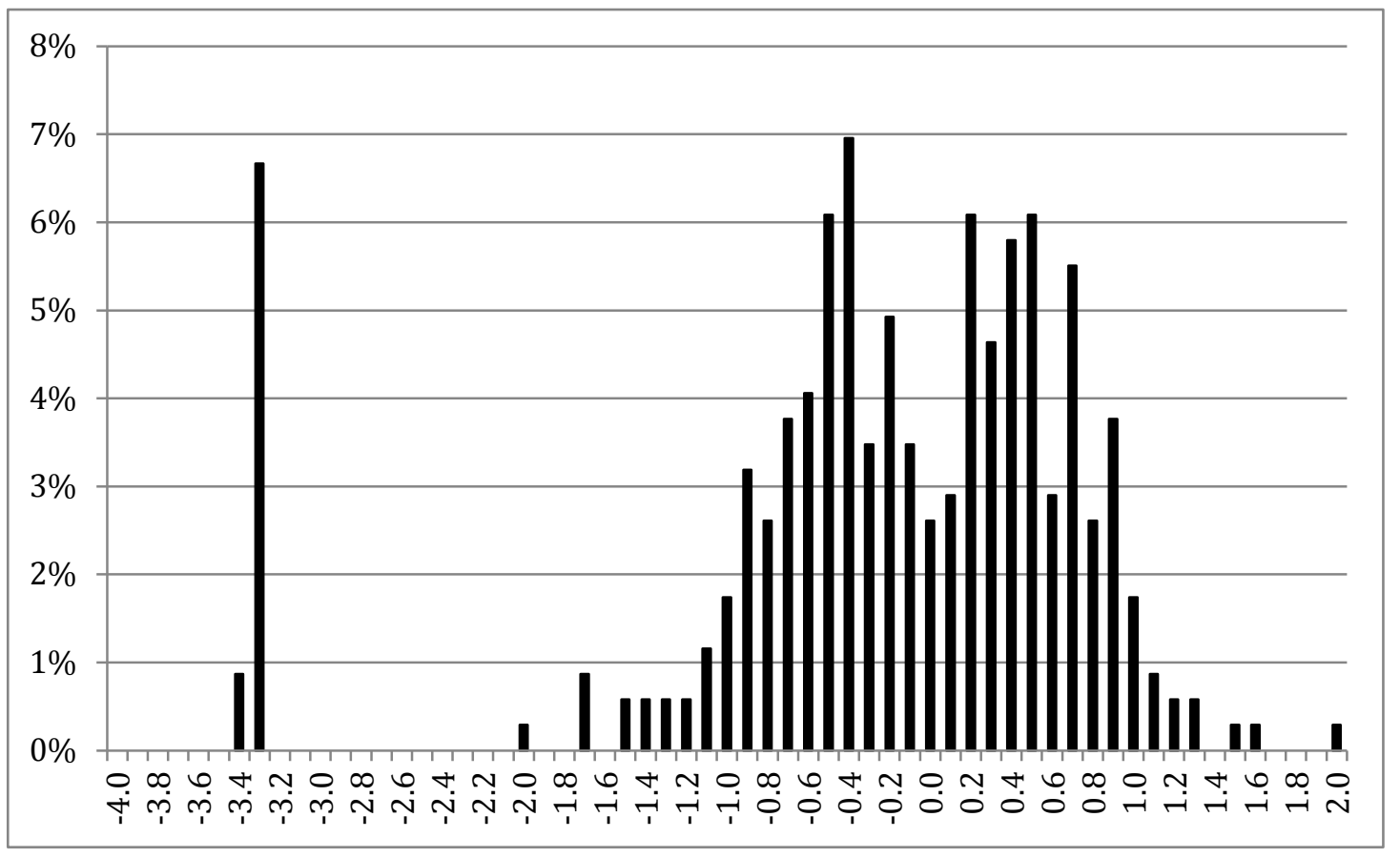

Figure 4: Histogram of the proportion of the sampled population with a given marginal willingness-topay for the agroforestry condition $\left(\mathrm{MWTP}_{\mathrm{AFC}}\right)$, measured as a change in annual interest rate of a loan $(\%)$. Categories on the $\mathrm{x}$-axis are $.1 \% \pm 0.05 \%$ change in annual interest rate. The results presented are from a simulated MWTP incorporating the attributes: condition, condition* $\operatorname{Ln}($ Crop value), and interest rate of the loan. It was simulated using 1000 Halton draws and the crop value data of the 345 households sampled. 


\begin{tabular}{|c|c|c|c|c|c|c|}
\hline 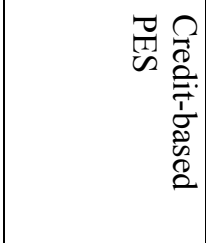 & 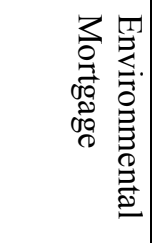 & $\begin{array}{l}\Omega \\
\stackrel{0}{0} \\
\stackrel{0}{D} \\
\stackrel{0}{\vec{D}}\end{array}$ & 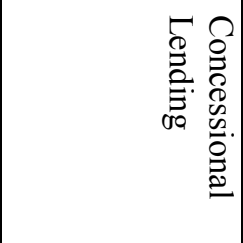 & 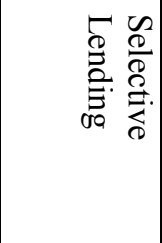 & 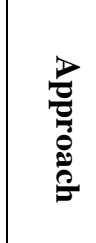 & \\
\hline 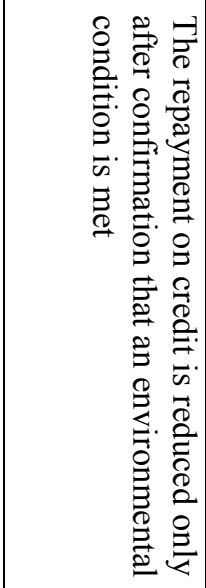 & 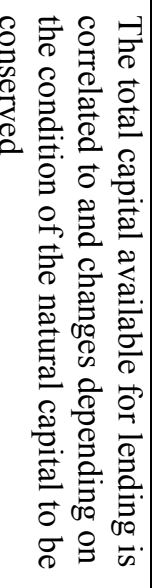 & 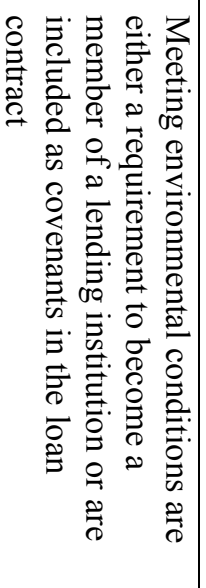 & 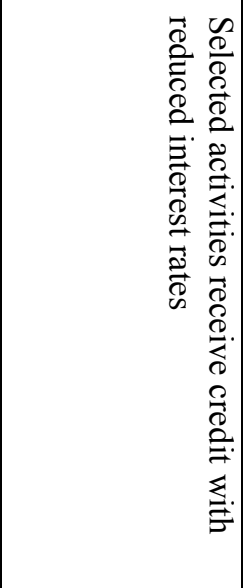 & 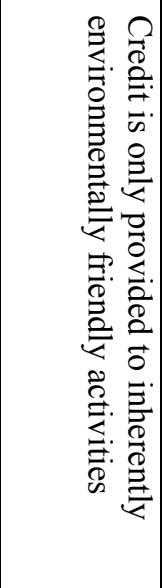 & 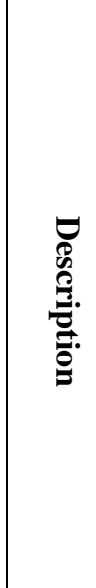 & \\
\hline 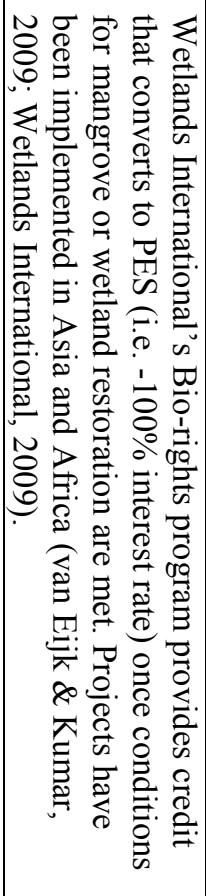 & 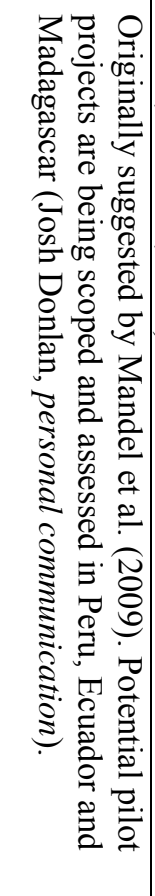 & 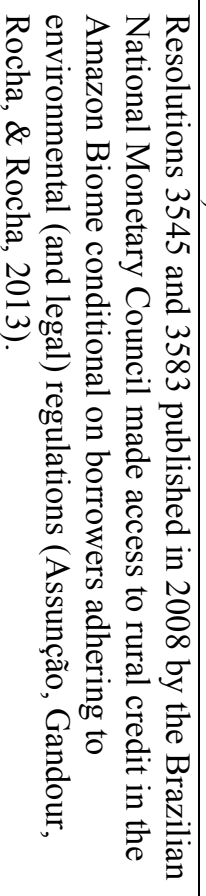 & 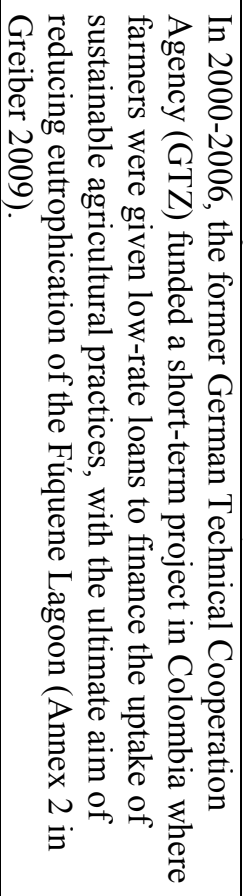 & 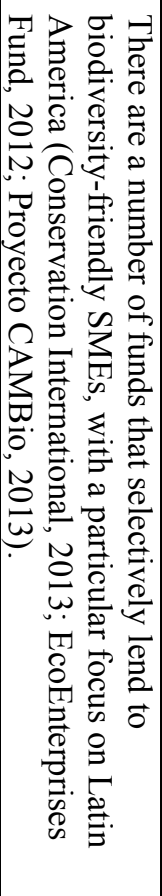 & 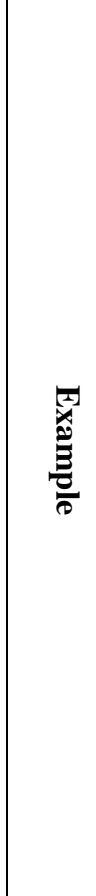 & \\
\hline $\begin{array}{l}\mathscr{C} \\
\overrightarrow{0} \\
\stackrel{\overrightarrow{0}}{\Xi}\end{array}$ & $\begin{array}{l}\mathscr{U} \\
\stackrel{0}{0} \\
\stackrel{9}{9 a}\end{array}$ & 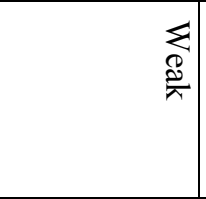 & 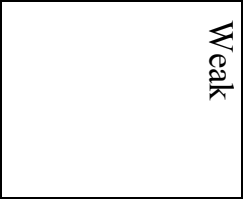 & $\begin{array}{l}\gtrless \\
\frac{8}{2}\end{array}$ & 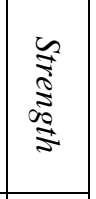 & \\
\hline$z$ & $z$ & $z$ & 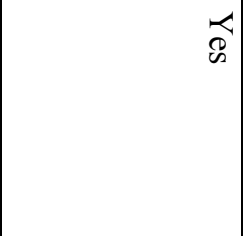 & $\overleftrightarrow{8}$ & 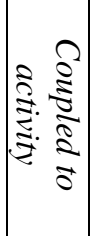 & \\
\hline 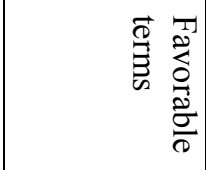 & 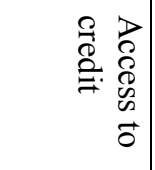 & 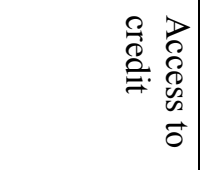 & 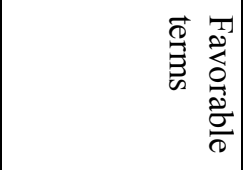 & \begin{tabular}{ll}
$\stackrel{3}{0}$ & $\overrightarrow{0}$ \\
0 & 0 \\
\hdashline & 0 \\
0 \\
0 \\
0 \\
$\overrightarrow{0}$
\end{tabular} & 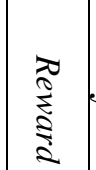 & : \\
\hline
\end{tabular}


Table 2: Summary of cash flow models of shade-grown coffee, mixed agroforestry, and sustainable forestry systems in the Intag River Region of Ecuador, compared to two conventional agricultural systems. Net present values (NPV) are per hectare, and assume that introduced production systems are implemented to a high quality.

\begin{tabular}{|l|c|c|c|}
\hline Production System & $\begin{array}{c}\text { NPV } \\
\text { 15 years }\end{array}$ & $\begin{array}{c}\text { NPV } \\
\text { 25 years }\end{array}$ & $\begin{array}{c}\text { Break Even } \\
\text { Year }\end{array}$ \\
\hline Shade-grown coffee $^{\mathrm{a}}$ & $\$ 15,571$ & $\$ 33,205$ & 2 \\
\hline Mixed agroforestry $^{\mathrm{a}}$ & $\$ 25,909$ & $\mathrm{n} / \mathrm{a}$ & 3 \\
\hline Sustainable forestry $^{\mathrm{a}}$ & $\$ 22,571$ & $\$ 25,071$ & 12 \\
\hline Mixed beans and corn (low) $^{\mathrm{b}}$ & $\$ 3,815$ & $\$ 5,180$ & $\mathrm{n} / \mathrm{a}$ \\
\hline Mixed beans and corn (high) $^{\mathrm{b}}$ & $\$ 10,604$ & $\$ 14,399$ & $\mathrm{n} / \mathrm{a}$ \\
\hline Sugar cane $^{\mathrm{b}}$ & $\$ 20,925$ & $\$ 28,413$ & $\mathrm{n} / \mathrm{a}$ \\
\hline
\end{tabular}

${ }^{a}$ Data provided by local agricultural expert (Jose Cueva, personal communication)

${ }^{\mathrm{b}}$ Annual cash flow estimates from (Martinet, 2006) as cited in (Kocian et al., 2011)

${ }^{c}$ Discount rate of 5\% 
Table 3: Attributes and levels for choice experiment in Intag agroforestry survey.

\begin{tabular}{|l|l|}
\hline Attribute & Levels \\
\hline Loan size & $\$ 1000, \$ 2500, \$ 5000$ \\
\hline Maturity & Short (1-2 years), Medium (3-5 years), Long (6-10 years) \\
\hline Conditionality & 1 if conditional loan, 0 if unconditional loan \\
\hline Interest rate & $0 \%, 5 \%, 12 \%, 18 \%$ \\
\hline
\end{tabular}


Table 4: Variables included in the models of loan choice. Attribute averages are calculated over all chosen alternatives and over chosen alternatives that were loans, household characteristic averages are calculated across all 345 households in the sample.

\begin{tabular}{|c|c|c|c|c|}
\hline $\begin{array}{l}\text { Variable } \\
\text { Type }\end{array}$ & Variable & Description & $\begin{array}{c}\text { Mean } \\
\text { [Min, Max] } \\
\text { (All Chosen } \\
\text { Alts.) }\end{array}$ & $\begin{array}{c}\text { Mean } \\
\text { [Min, Max] } \\
\text { (Only if Loan } \\
\text { Chosen) }\end{array}$ \\
\hline \multirow{5}{*}{ 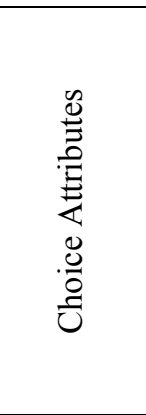 } & Loan & $=1$ if choice alternative is a loan & $\begin{array}{c}0.87 \\
{[0,1]}\end{array}$ & $\begin{array}{c}1 \\
{[1,1]}\end{array}$ \\
\hline & $\begin{array}{l}\text { Size of } \\
\text { loan }\end{array}$ & In US\$, scaled by $1 / 1000$ & $\begin{array}{c}2387.30 \\
{[0,5000]}\end{array}$ & $\begin{array}{c}2785.19 \\
{[1000,5000]}\end{array}$ \\
\hline & $\begin{array}{l}\text { Payback } \\
\text { period }\end{array}$ & Maturity of loan, in years & $\begin{array}{c}3.66 \\
{[0,8]}\end{array}$ & $\begin{array}{c}4.27 \\
{[1.5,8]} \\
\end{array}$ \\
\hline & Condition & $=1$ if agroforestry condition applied & $\begin{array}{c}0.41 \\
{[0,1]}\end{array}$ & $\begin{array}{c}0.48 \\
{[0,1]}\end{array}$ \\
\hline & $\begin{array}{l}\text { Interest } \\
\text { rate }\end{array}$ & Annual rate as a $\%$, i.e. $5 \%=5$ & $\begin{array}{c}3.49 \\
{[0,18]}\end{array}$ & $\begin{array}{c}4.07 \\
{[0,18]}\end{array}$ \\
\hline \multirow{4}{*}{ 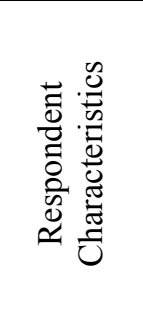 } & $\begin{array}{l}\text { Afford } \\
\text { loan }\end{array}$ & $\begin{array}{l}=1 \text { if household's annual gross cash } \\
\text { income }>\text { than size of chosen loan }\end{array}$ & $\begin{array}{c}0.75 \\
{[0,1]}\end{array}$ & $\begin{array}{c}0.71 \\
{[0,1]}\end{array}$ \\
\hline & Titled land & $\begin{array}{l}=1 \text { if a household claims title to some } \\
\text { land }\end{array}$ & \multicolumn{2}{|c|}{$\begin{array}{c}0.63 \\
{[0,1]}\end{array}$} \\
\hline & Crop value & $\begin{array}{l}\text { US\$ value of all crops produced in } \\
2010\end{array}$ & \multicolumn{2}{|c|}{$\begin{array}{c}3912.56 \\
{[0,132650]}\end{array}$} \\
\hline & Children & Number of children in household & \multicolumn{2}{|c|}{$\begin{array}{c}1.37 \\
{[0,7]}\end{array}$} \\
\hline
\end{tabular}


Table 5: Select descriptive statistics of the sample compared with information from censuses and other studies. INEC (2010) is the population census in the same year as this study, carried out by Instituto Nacional de Estadística y Censos (INEC). INEC (2000) is the most recent agricultural census, carried out by INEC and Ministerio de Agricultura, Ganadería, Acuacultura y Pesca (MAG). Arisman (2012) is a study focused on agroforestry in Intag that also used an opportunistic sample of 41 households and tried to survey the head of each household.

\begin{tabular}{|c|c|c|c|c|}
\hline \multirow{2}{*}{ Description (units) } & \multirow{2}{*}{$\begin{array}{c}\text { Sample } \\
\text { Value }\end{array}$} & \multicolumn{3}{|c|}{ Comparison } \\
\hline & & Value & Scale & Source \\
\hline \multicolumn{5}{|l|}{ Respondent } \\
\hline Average Age (years) & 50 & 51 & Intag & Arisman (2012) \\
\hline \multicolumn{5}{|l|}{ Household } \\
\hline Average household size (people) & 3.7 & 4 & Intag & Arisman (2012) \\
\hline Titled land $(\%$ of $\mathrm{HH})$ & 64 & 70 & Imbabura $^{\mathrm{a}}$ & INEC (2000) \\
\hline \multirow[t]{2}{*}{ Average farm size $(\mathrm{Ha})$} & \multirow[t]{2}{*}{15.4} & 14.7 & Cotacachi $^{\mathrm{b}}$ & INEC (2000) \\
\hline & & 17 & Intag & Arisman (2012) \\
\hline \multicolumn{5}{|l|}{ Population/Sample } \\
\hline Achieved $1^{\circ}$ education $(\%)$ & 77 & 67 & Intag $(\text { men })^{\mathrm{c}}$ & INEC (2010) \\
\hline Achieved $>1^{\circ}$ education $(\%)$ & 8 & 20 & Intag (men) ${ }^{\mathrm{c}}$ & INEC (2010) \\
\hline Under 18 years of age $(\%)$ & 38 & 42 & Intag & INEC (2010) \\
\hline
\end{tabular}

${ }^{\mathrm{a}}$ Intag is located in, but comprises a small area of, Imbabura province.

${ }^{\mathrm{b}}$ Intag includes seven parishes, six of which are located in and comprise $\sim 75 \%$ (by area) of Cotacachi county.

${ }^{c} 93 \%$ of survey respondents were male, making the comparison to men only more meaningful than a comparison to the entire mixed population. 


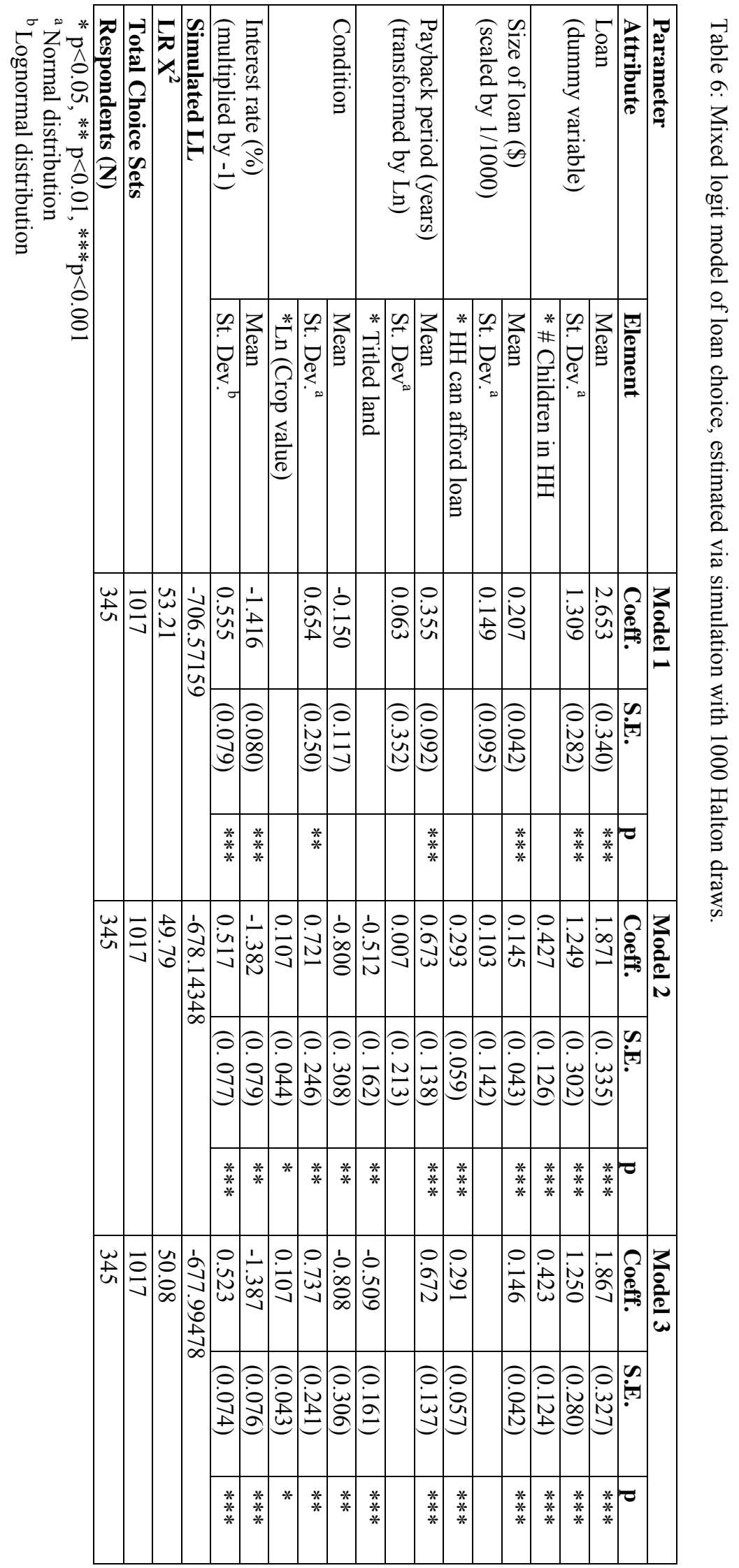


Table 7: Mean marginal willingness to pay (MWTP) for a loan where annual interest rate (\%) is the price parameter. Simulations carried out with 1000 Halton draws.

\begin{tabular}{|c|c|c|c|}
\hline Attribute & Parameter & $\begin{array}{c}\text { MWTP } \\
{[95 \% \text { C.I. }]^{\mathrm{c}}}\end{array}$ & $\begin{array}{c}\text { Simulated MWTP }[95 \% \\
\text { C.I. }]^{\mathrm{d}}\end{array}$ \\
\hline \multirow[t]{2}{*}{$\begin{array}{l}\text { Loan } \\
\text { (dummy variable) }\end{array}$} & $(\text { main effect) })^{a}$ & $\begin{array}{c}6.516 \\
{[4.484,8.549]}\end{array}$ & $\begin{array}{c}7.773 \\
{[-2.011,20.824]}\end{array}$ \\
\hline & * \# Children in $\mathrm{HH}^{\mathrm{b}}$ & $\begin{array}{c}1.478 \\
{[0.643,2.313]}\end{array}$ & $\begin{array}{c}1.761 \\
{[0.977,2.940]}\end{array}$ \\
\hline \multirow[t]{2}{*}{$\begin{array}{l}\text { Size of loan }(\$) \\
\text { (scaled by } 1 / 1000)\end{array}$} & $\left(\right.$ main effect) ${ }^{b}$ & $\begin{array}{c}0.511 \\
{[0.226,0.796]}\end{array}$ & $\begin{array}{c}0.609 \\
{[0.338,1.016]}\end{array}$ \\
\hline & $* \mathrm{HH}$ can afford loan ${ }^{b}$ & $\begin{array}{c}1.015 \\
{[0.632,1.398]}\end{array}$ & $\begin{array}{c}1.209 \\
{[0.671,2.018]}\end{array}$ \\
\hline \multirow[t]{2}{*}{$\begin{array}{l}\text { Payback period (years) } \\
\text { (transformed by Ln) }\end{array}$} & $\left(\right.$ main effect) ${ }^{b}$ & $\begin{array}{c}2.347 \\
{[1.391,3.303]}\end{array}$ & $\begin{array}{c}2.796 \\
{[1.551,4.667]}\end{array}$ \\
\hline & $*$ Titled land $^{\mathrm{b}}$ & $\begin{array}{c}-1.777 \\
{[-2.866,-0.688]}\end{array}$ & $\begin{array}{c}-2.117 \\
{[-3.533,-1.174]}\end{array}$ \\
\hline \multirow[t]{2}{*}{ Condition } & $\left(\right.$ main effect) ${ }^{\mathrm{a}}$ & $\begin{array}{c}-2.822 \\
{[-4.908,-0.736]}\end{array}$ & $\begin{array}{c}-3.347 \\
{[-10.826,2.392]}\end{array}$ \\
\hline & $* \operatorname{Ln}(\text { Crop Value })^{b}$ & $\begin{array}{c}0.375 \\
{[0.081,0.670]}\end{array}$ & $\begin{array}{c}0.447 \\
{[0.248,0.746]}\end{array}$ \\
\hline
\end{tabular}

${ }^{a}$ Simulated MWTP has a random parameter in numerator and denominator

${ }^{\mathrm{b}}$ Simulated MWTP has a random parameter in denominator only because the numerator is either an attribute modelled with a fixed parameter or an interaction term (which were all modeled as fixed parameters).

${ }^{\mathrm{c}}$ Estimated via delta method

${ }^{\mathrm{d}}$ Estimated via Krinsky-Robb method 
Table 8: Three subgroups with differing MWTP for the agroforestry condition (MWTP $\left.\mathrm{AFC}_{\mathrm{AF}}\right)$, measured as a change in annual interest rate $(\%)$.

\begin{tabular}{|c|c|c|c|c|}
\hline Group & $(+) \mathbf{M W T P}_{\mathrm{AFC}}$ & $(-) \mathbf{M W T P} \mathbf{P}_{\mathrm{AFC}}$ & $(--) M W T P_{A F C}$ & $\begin{array}{l}\text { Whole } \\
\text { Sample }\end{array}$ \\
\hline Mean MWTP AFC $_{\text {A }}$ & $0.53 \%$ & $-0.58 \%$ & $-3.31 \%$ & $-0.27 \%$ \\
\hline Max. MWTP ${ }_{\mathrm{AFC}}$ & $1.99 \%$ & $-0.01 \%$ & $-3.26 \%$ & $1.99 \%$ \\
\hline Min. MWTP ${ }_{\mathrm{AFC}}$ & $0.02 \%$ & $-1.98 \%$ & $-3.39 \%$ & $-3.39 \%$ \\
\hline $\begin{array}{l}\text { Portion of } \\
\text { Population }\end{array}$ & $46.38 \%$ & $46.09 \%$ & $7.54 \%$ & $100.00 \%$ \\
\hline
\end{tabular}


Table 9: Simulating demand for loans with an agroforesty condition, based on a $\$ 2500$, 4-year loan in a choice set with 1) the same unconditional loan at $12 \%$ interest, or 2) no-loan status quo. The second to last column indicates the portion of the CB-PES that corresponds to compensation for the marginal change in welfare associated with the PES condition, averaged based on expected participation in CBPES at a given interest rate. The last column is the same statistic, but averaged over the entire sample.

\begin{tabular}{|c|c|c|c|c|c|}
\hline $\begin{array}{c}\text { Interest } \\
\text { Rate } \\
(\%)\end{array}$ & $\begin{array}{c}\text { Predicted } \\
\text { Demand } \\
(\%)\end{array}$ & $\begin{array}{c}\text { CB- } \\
\text { PES } \\
(\mathbf{\%} / \text { year })\end{array}$ & $\begin{array}{c}\text { CB-PES as \% } \\
\text { of annual loan } \\
\text { repayment }\end{array}$ & $\begin{array}{c}\text { Mean \% of CB-PES } \\
\text { that compensates } \\
\text { self-selecting } \\
\text { participators }\end{array}$ & $\begin{array}{c}\text { Mean \% of CB-PES } \\
\text { that compensates } \\
\text { across whole sample }\end{array}$ \\
\hline 12 & 34.89 & - & - & - & - \\
\hline 10 & 45.50 & 34.41 & 4.18 & 3.51 & 13.28 \\
\hline 8 & 56.15 & 68.28 & 8.30 & 2.43 & 6.59 \\
\hline 6 & 66.31 & 101.61 & 12.34 & 2.11 & 3.35 \\
\hline 4 & 75.15 & 134.36 & 16.32 & 1.94 & 2.56 \\
\hline 2 & 82.26 & 166.53 & 20.23 & 1.79 & 2.11 \\
\hline 0 & 87.61 & 198.09 & 24.07 & 1.65 & \\
\hline
\end{tabular}


Table 10: Comparing the annual loan repayment if the condition is met to the repayment required if the condition is not met, expressed in both \$/year and as a \% of reported 12 -month gross cash income.

Both are estimated as a mean expected value of the portion of the population that it is predicted would accept CB-PES at the interest rate given. Based on a \$2500, 4-year loan.

\begin{tabular}{|c|c|c|c|c|}
\hline \multicolumn{3}{|c|}{ Condition is Met } & \multicolumn{2}{c|}{ Condition is Not Met (12\% Interest Rate) } \\
\hline $\begin{array}{c}\text { Interest } \\
\text { Rate }\end{array}$ & Repayment (\$/year) & $\begin{array}{c}\text { Repayment as \% of } \\
\text { Gross Cash Income }\end{array}$ & Repayment (\$/year) & $\begin{array}{c}\text { Repayment as \% of } \\
\text { Gross Cash Income }\end{array}$ \\
\hline $12 \%$ & $\$ 823$ & $12.65 \%$ & $\$ 823$ & $12.65 \%$ \\
\hline $10 \%$ & $\$ 787$ & $15.67 \%$ & $\$ 823$ & $16.32 \%$ \\
\hline $8 \%$ & $\$ 755$ & $18.64 \%$ & $\$ 823$ & $20.28 \%$ \\
\hline $6 \%$ & $\$ 721$ & $21.25 \%$ & $\$ 823$ & $24.16 \%$ \\
\hline $4 \%$ & $\$ 689$ & $23.22 \%$ & $\$ 823$ & $27.64 \%$ \\
\hline $2 \%$ & $\$ 657$ & $24.45 \%$ & $\$ 823$ & $30.51 \%$ \\
\hline $0 \%$ & $\$ 625$ & $24.98 \%$ & $\$ 823$ & $32.72 \%$ \\
\hline
\end{tabular}

